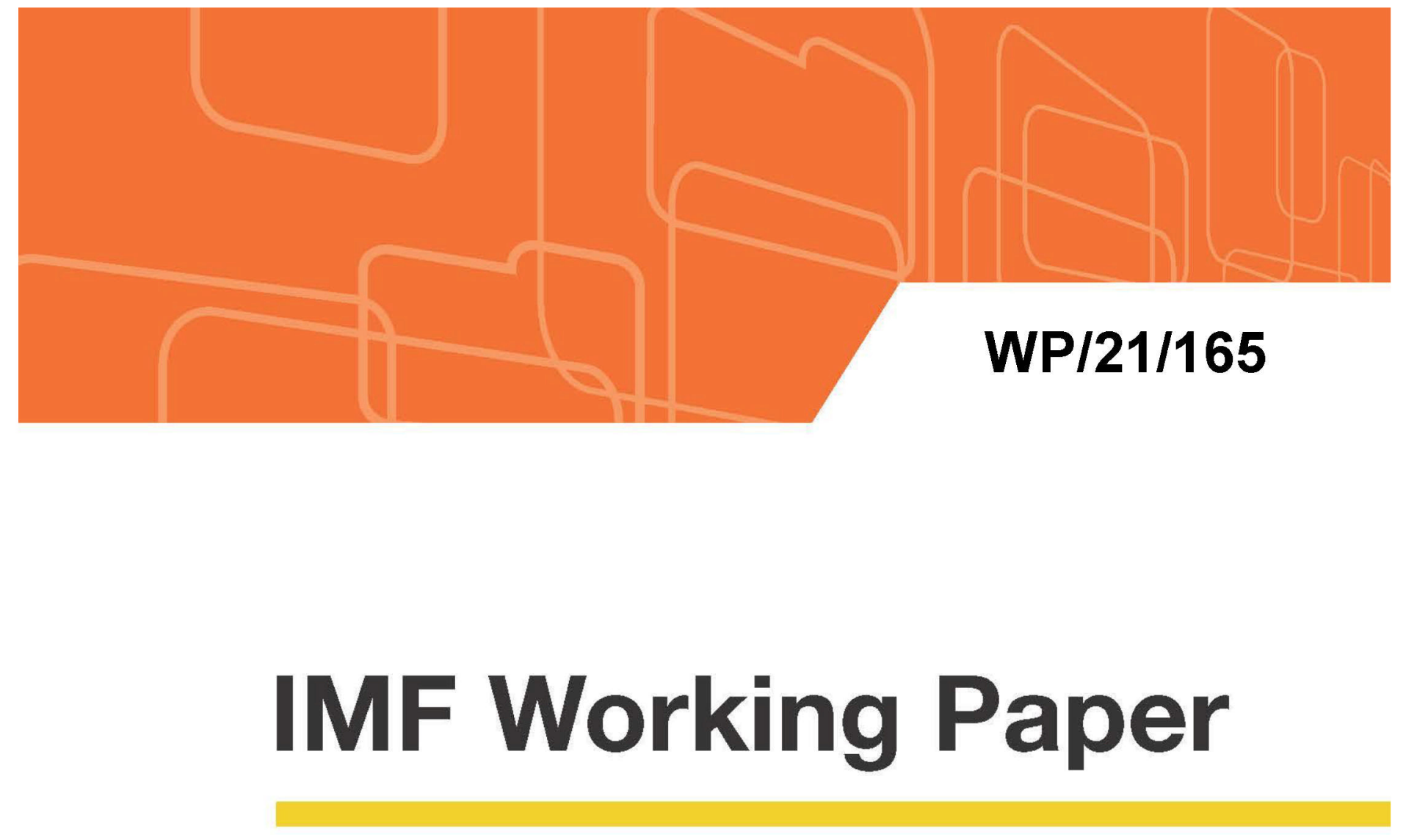

\title{
Labor Market Reform Options to Boost Employment in South Africa
}

by Romain Duval, Yi Ji, Ippei Shibata

IMF Working Papers describe research in progress by the author(s) and are published to elicit comments and to encourage debate. The views expressed in IMF Working Papers are those of the author(s) and do not necessarily represent the views of the IMF, its Executive Board, or IMF management.

$$
\text { I N T E R N A T I O N A L M O N E T A R Y F U N D }
$$




\title{
IMF Working Paper
}

Research Department

\section{Labor Market Reform Options to Boost Employment in South Africa \\ Prepared by Romain Duval, Ippei Shibata and Yi Ji}

Authorized for distribution by Romain Duval

June 2021

\begin{abstract}
IMF Working Papers describe research in progress by the author(s) and are published to elicit comments and to encourage debate. The views expressed in IMF Working Papers are those of the author(s) and do not necessarily represent the views of the IMF, its Executive Board, or IMF management.
\end{abstract}

\begin{abstract}
Raising South Africa's low employment rate to levels seen in emerging market or advanced economy peers could raise GDP per capita by 50 to 60 percent and reduce income inequality dramatically in the long term. By putting further strain on an already fragile labor market, Covid-19 has raised the urgency of action. This paper reviews labor market policy and other reform options to enhance South Africa's job market performance, drawing from international evidence and new analysis. We find much scope for improving the design of key labor market institutions - including collective bargaining and employment protection legislation - and active labor market policies to improve job seekers' prospects. These reforms should come hand-in-hand with others, such as in the areas of education or product market regulation, that may work pay. Labor market and other reforms would primarily benefit disadvantaged groups such as youth.
\end{abstract}

JEL Classification Numbers: E24, J08, J21, J38, J58, L51, O43, O55

Keywords: South Africa; labor market; unemployment; structural reform; collective bargaining; minimum wage; employment protection; active labor market policies; product market; youth employment.

Author’s E-Mail Address: $\underline{\text { rduval@imf.org, ishibata@imf.org, Yji@imf.org }}$ 
ABSTRACT

I. INTRODUCTION AND SUMMARY OF MAIN FINDINGS

II. LABOR MARKET PERFORMANCE IN SOUTH AFRICA: A BRIEF OVERVIEW

III. IMPROVING THE FUNCTIONING OF KEY LABOR MARKET INSTITUTIONS

11

IV. STRENGTHENING LABOR FORCE EMPLOYABILITY

23

V. LIFTING YOUTH JOB PROSPECTS

26

VI. CONCLUSION

30

VII. APPENDIXI. MODEL-BASED ANALYSIS OF WAGE BARGAINING REFORM IN SOUTH AFRICA

FIGURES

1. Employment Rates $\underline{4}$

2. Employment and labor force participation rates 4

3. Unemployment Rate___ $\underline{5}$

4. Cyclical Sensitivity of Unemployment___ $\underline{5}$

5. Unemployment Rate (by age)___ $\underline{9}$

6. Unemployment Rate (by Education) __ $\underline{9}$

7. Unemployment Rate (by Race)___ $\underline{9}$

8. Shift-share analysis of unemployment in South Africa ___ $\underline{9}$

9. Union density and Bargaining coverage Rate___ 12

10. Centralization of Bargaining ___ 15

11. Industrial disputes__ 16

12. Cooperation in employee-employer relations___ 16

13. Minimum-to-median wage ratios__ 17

14. Estimated impact on unemployment and job flows of wage bargaining flexibility at the firm level 19

15. Number of annual cases referred to the CCMA___ $\underline{20}$

16. Stringency of Product Market Regulations ___ 24

17. Percentage of Firms with a Bank Loan or Credit Line__ $\underline{24}$

19. Youth Gender Gaps__ $\underline{26}$

18. Youth Labor Market Performance __ $\underline{26}$

20. Employment Rates for Youth and Adults___ 27

22. Job Quality Effects of Structural Policies and Characteristics ___ 29

A1 Estimated Impact on Unemployment and Job Flows of Wage Bargaining Flexiblity at the Firm _ $\underline{38}$

TABLES

1. A (very) Simplified taconomy of taxono my of collective bargaining systems around the world___ 14

2. Calibration of Model Parameters___ $\underline{38}$ 


\section{INTRODUCTION AND SUMMARY OF MAIN FINDINGS ${ }^{1}$}

\section{Boosting employment from its very low level is key to lifting GDP per capita} growth and reducing high income inequality in South Africa. The aggregate employment rate is very low in international comparison (Figure 1), reflecting both low labor force participation and very high unemployment. Further, the gap vis-àvis peers has been growing over time. If the employment rate was equal to the OECD average or the average across the best emerging market (EM) performers, GDP per capita might be 50 to 60 percent above its current level, all else equal. ${ }^{2}$ Because the incidence of

Figure 1: Employment rates (percent)

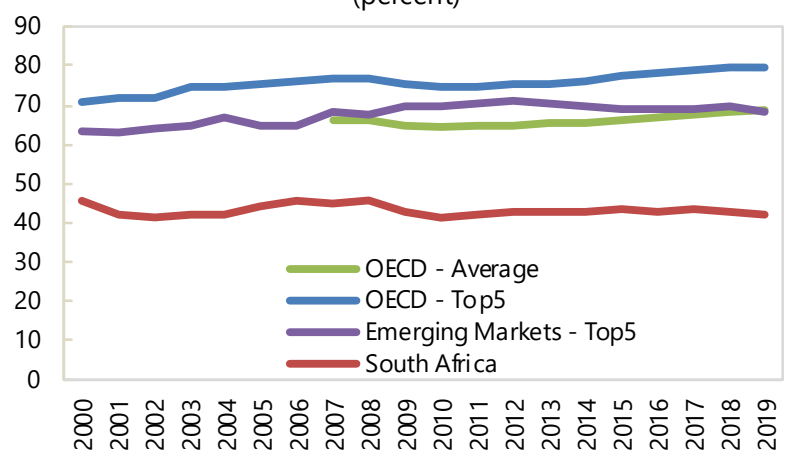

Source: South Africa Statistics LFS (2000-2007), QLFS (2008-2019); OECD Labor Market Statistics; ILO STAT; IMF staff calculations. Note: Top 5 aggregates are computed as the simple average of the five countries with the highest employment rates in the latest year. non-employment also falls disproportionately onto lower incomes - being particularly high among youth and black Africans, boosting employment would also reduce income inequality. Past IMF estimates (Anand, Khotari and Kumar, 2016) suggest that a 10 percentage point reduction in the unemployment rate could lower the Gini index (after tax and transfers) by 3 percentage points.

\section{The Covid-19 crisis has hit} South Africa's labor market hard, fostering massive cyclical underemployment. Partly as a result of the stringency of containment measures, the employment rate fell by 6 percentage points (to just $36 \%$ ) between 2020Q1 and 2020Q2, as people dropped out of the labor force - the labor force participation rate fell by 13 percentage points (to
Figure 2: Employment and labor force participation rates (2017Q1-2020Q4, percent)

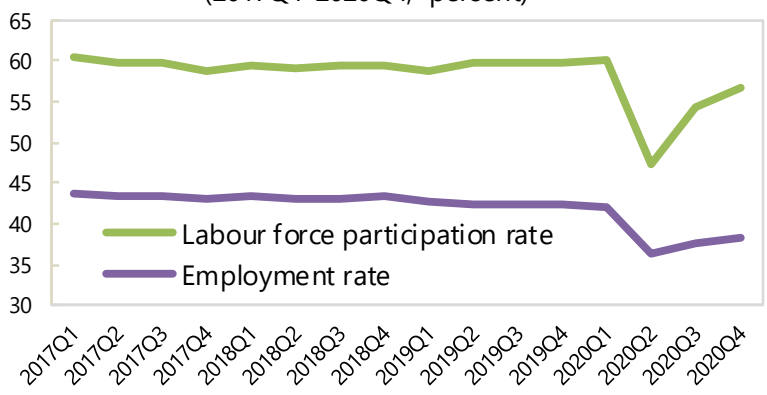

Source: South Africa Quarterly Labour Force Statistics.

\footnotetext{
${ }^{1}$ The authors would like to thank, without implication, Ana Lucia Coronel, Haonan Qu, Alejandro Simone and Vimal Thakoor for their helpful comments. All views and errors are those of the authors.

${ }^{2}$ The figure would be 60 percent in a simple illustrative calculation that assumes an aggregate Cobb-Douglas production function with constant returns to scale, exogenous (given) total factor productivity, and full adjustment of the capital stock to higher employment in the long term. Insofar as the skills and intrinsic productivity of the non-employed are less than those of employed workers, the potential income gains from raising employment rates would be smaller, but still quite sizeable. For example, using Bourlès and Cette's (2007) estimates of the (negative) impact of higher overall employment on aggregate productivity across a sample of OECD countries, South Africa's GDP per capita could still rise by close to 50 percent if its employment rate rose to average OECD or top 5 emerging market levels.
} 
$47 \%$ ) over this same period (Figure 2). Because job seekers also had to temporarily stop looking for jobs, the unemployment rate dropped temporarily (by 7 percentage points, to just over $23 \%$ ). Even though the labor market recovered as people came back to the labor force starting from 2020Q3, the employment rate remained over 4 percentage points below its preCOVID rate in 2020Q4, and the unemployment rate bounced back up to over 32 percent-roughly 3 percentage points above its very high pre-COVID Figure 3: Unemployment rate (2017Q1-2020Q4, percent) rate (Figure 3).

3. This lack of labor market resilience is not unique to this crisis. While the Covid19 shock was unique in many ways, South Africa's labor market has long shown limited resilience to shocks. Based on Okun law estimates, unemployment is more responsive to the business cycle in South Africa than in the average EM, partly reflecting the rather low prevalence of informality. ${ }^{3}$ However, it is also more responsive than in the average advanced economy (AE), partly because labor market institutions are not conducive to employment-stabilizing wage and/or hours adjustment in downturns, as discussed further below (Figure 4). Moreover, the cyclicality of disadvantaged groups' (un)employment rates is disproportionately high in South Africa-for example, youth employment is about twice as cyclical as aggregate employment, and more cyclical than in other EMs and AEs.

\section{But South Africa's employment problem is primarily structural, reflecting a} mismatch between existing labor supply and demand at prevailing market wages. While it has fluctuated over time, South Africa's unemployment rate never fell below 20 percent during the last two decades, and even slowly rose over time to reach about 30 percent — one of the highest levels in the world. This clearly indicates that very high unemployment is

\footnotetext{
${ }^{3}$ While informality is typically associated with weaker productivity and other social and economic costs, it acts as a labor market buffer and, as such, reduces the sensitivity of total employment to macroeconomic shocks in many EMDEs. For IMF analysis of the impact of informality on Okun law coefficients, see Bluedorn and others (2019).
} 
structural. On the supply side, low education and entrepreneurship tend to reduce the employability of job seekers, while high commuting costs raise reservation wages - that is, the minimum wage levels above which job seekers would be willing to take up a job offer (Ngarachu, Schimmelpfennig and Schoer, 2014). Some grants might also raise reservation wages, albeit indirectly and to a lesser extent. On the demand side, labor market institutions - such as wage-bargaining arrangements - further raise wages above levels that would be needed to clear the labor market.

5. A number of these forces can be traced back to apartheid. Apartheid directly contributed to low education levels among of a large fraction of the working-age population and geographical remoteness of job seekers from job centers. It also indirectly led to a corrective set of institutions and regulations, such as collective bargaining arrangements and job protection, that emphasize formal arbitration and legal procedures over more informal social dialogue and conflict resolution, with adverse effects on employment and broader economic efficiency. Likewise, the suppression of formal black entrepreneurship under apartheid partly accounts for the persistent negative perception of the informal economy among the population, while in many other emerging economies informality provides an important employment buffer - albeit at a productivity cost.

\section{A bold strategy to reform labor market institutions is needed to tackle the root} causes of extreme structural unemployment. To raise employment and reduce inequality, labor market institutions need to function more smoothly - with a focus on strengthening coordination among social partners, accommodating firm heterogeneity and reducing uncertainty. This requires reforms in the areas of collective bargaining and employment protection legislation, as well as careful minimum wage setting. Being regulatory reforms, these have the further advantage of not requiring government spending - unlike other desirable policy changes that should wait until fiscal space is restored. And if properly designed and swiftly implemented, they could speed up the jobs recovery from the Covid-19 shock. Specifically:

- $\quad$ South Africa's collective bargaining system currently lacks some of the key ingredients that have underpinned the success of sector-level bargaining in some other (mostly advanced) countries - strong coordination between different sectors, high trust between partners, representative bargaining parties and a dose of firm-level flexibility. International experience suggests that, to achieve higher and more stable employment, South Africa would either need to build these demanding ingredients into its sector-level bargaining system or, alternatively, decentralize bargaining at the firm level.

- Wage bargaining coordination could be strengthened by adopting a norm that facilitates negotiation (productivity gains, inflation), and having the government highlight more prominently in the process the employment cost of excessive wage growth. Frequent negotiations could also help gradually foster trust between partners, which in turn would be a key ingredient for greater coordination to pay off. Should fostering coordination and trust prove too difficult or fail to generate wage 
moderation and employment gains, there would be a case for decentralizing bargaining at the firm level altogether.

- $\quad$ The current system could be improved in several other ways. The representativeness of bargaining councils could be strengthened by setting and enforcing clear quantitative criteria for whether they are "sufficiently representative"-for example, a requirement that bargaining parties represent the majority of employees and employers in the industry for a bargaining council to be established. Likewise, clear criteria for administrative extensions of collective agreements, such as a requirement that signatory employers' organizations represent at least the majority of the total number of employers, would help, and in any event the Minister could retain the ability to reject the extension if not deemed in the economy's interest. Finally, firmlevel flexibility is key. New analysis in this paper finds that simply introducing flexible opening clauses that enable individual firms to adjust wages and hours worked when facing hardship could speed up return to full employment in the wake of shocks - such as Covid-19 - and cut overall structural unemployment by a minimum of 2 percentage points.

- $\quad$ Minimum wage setting should carefully balance reducing in-work poverty and enhancing the job prospects of disadvantaged groups - both are key to reducing poverty and income inequality. South Africa's minimum-to-median wage ratio is high in international comparison - above the vast majority of EMs' and much higher than in any AE. The annual review conducted by the National Minimum wage (NMW) Commission should be informed by independent evaluations of the NMW's effects on the job prospects of disadvantaged groups. Accordingly, the Commission should feel free to recommend, and the government to consider both upward and downward NMW adjustments depending on those job prospects, as well as overall macroeconomic conditions - including overall productivity growth. Over the medium term, as fiscal space is restored, one way to meet both employment and in-work poverty objectives could be to introduce in-work tax credits targeted at low incomes in exchange for minimum wage moderation.

- $\quad$ Employment protection legislation (EPL) provides important legal protection against discrimination, but the obstacles it puts to econ omic layoffs should be kept moderate, simple and efficiently enforced. EPL enforcement is burdensome and slow, and the outcome of dispute resolution processes can vary widely, creating undue uncertainty for employers and employees. Reform should focus on reducing caseloads, shortening further dispute resolution procedures, and strengthening the predictability of settlements. Streamlining EPL enforcement would not only support productivity and income per capita, but also reduce labor market dualism; employers could become less hesitant to offer regular jobs, and rely less on temporary contracts including temporary employment services (so-called labor brokers). To minimize risks that easier EPL might amplify layoffs in the short term, it could be enacted now with a provision that it will come into force only later-when economic conditions are stronger - or, alternatively, be grandfathered - that is, new rules and streamlined procedures would apply only to new contracts. Delayed implementation or grandfathering may also make it easier to pass EPL reform in the first place. 
7. While the focus of this paper is on improving the functioning of key labor market institutions, this should come hand in hand with reforms that increase returns to work for job seekers - these could remain too low for most job seekers to move into employment even with sound labor market institutions, muting the gains from reforming the latter. In particular, returns to work are depressed by: low education, which weakens productivity and prospective wages; low entrepreneurship, which further limits the range of high-value formal job opportunities; and the high ancillary costs of performing jobs, notably high transportation costs, which reduce (net) take-home pay. Boosting returns to work and employment requires a combination of pro-competition product market reforms - particularly in transport, stronger entrepreneurship including through improved access to cred it for small and medium enterprises (SMEs), enhanced education and apprenticeship schemes, and some "activation" of social benefit recipients. While a detailed discussion of these issues goes beyond the scope of the present paper (for some analysis of product market competition issues in the South African context, see Thakoor, 2020), they are briefly touched upon in Section IV.

8. Many of these reforms will help disproportionately disadvantaged groups in the labor market, notably youth. Empirical analysis using cross-country individual-level data finds a very strong correlation between youth and adult employment rates, suggesting that a broad reform agenda to help the latter will disproportionately benefit the former - more than measures that would be specifically targeted to youth. In particular, there is evidence that keeping minimum wages and EPL moderate, and strengthening product market competition, disproportionately benefits youth. Some consideration could also be given to introducing sub-minimum wages for youth, which exist in some other countries. Finally, strengthening legal protection for women could help reduce youth gender gaps in labor market integration, at a time when they are rising.

\section{LABOR MARKET PERFORMANCE IN SOUTH AFRICA: A BRIEF OVERVIEW}

9. South Africa's very low employment rate reflects both low labor force participation and very high structural unemployment. Very high unemployment, which was already on the rise prior to COVID-19, partly accounts for low participation by discouraging job search. Discouraged workers - those would like to work but are not actively looking for a job for lack of perceived opportunities - accounted for about 12 percent of the labor force in 2019; including them in the unemployment statistics would raise the (broadly defined) unemployment rate to over 40 percent. 


\section{Very high unemployment is heavily concentrated on youth and the lower-}

middle skilled. The unemployment rate of the 15-24 years old reached 57 percent in 2019 , versus just 10 percent for the 55-64 years old (Figure 5). While the very low-skilled (those without primary education) suffer high unemployment, the lower-middle-skilled suffer even more; about 35 percent of labor force participants with basic education (primary or lower secondary education) were unemployed in 2019 , versus 25 percent of those without basic education (and just 13 percent of those with an advanced (tertiary) degree) (Figure 6). Because of comparatively lower labor market participation, just 25 percent of the former had a job in 2019, versus 30 percent of the latter (and 71 percent of the working-age population with an advanced degree).

Figure 5: Unemployment rate (by age)

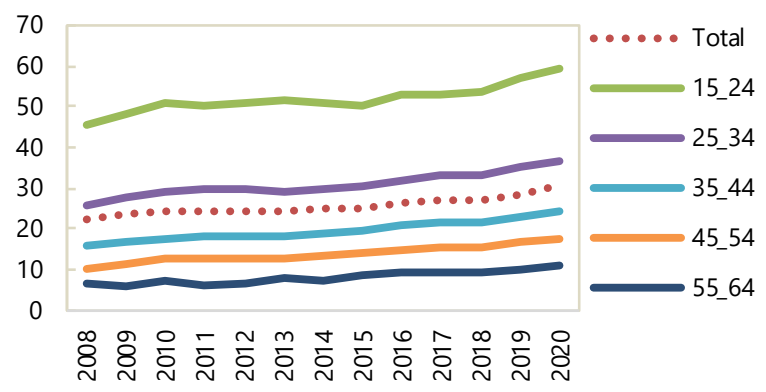

Source: ILO STAT.

Note: Age group in 10-year bands.
Figure 6: Unemployment rate (by education)

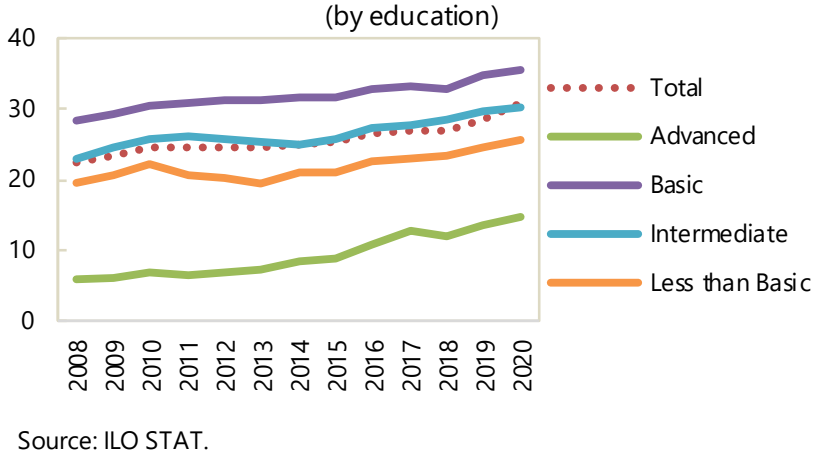

11. Major racial disparities in labor market performance persist. Black

Africans of working age are less likely than their white counterparts to participate in the labor force, and to be employed when participating. The gap in labor force participation in 2019 was about 10 percentage points ( 68 versus 58 percent), the gap in unemployment rates was over 25 percentage points (Figure 7).

Figure 7: Unemployment rate

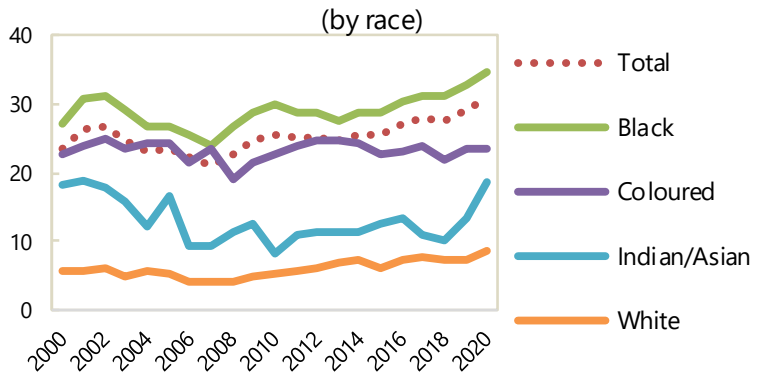

Source: South Africa Statistics LFS (2000-2007), QLFS (2008-2020).

12. The trend rise in unemployment is also heavily concentrated on youth, the lower-middle skilled-in line with South Africa's high exposure to task routinization (Ahn and others, 2019) — and the black African population. A simple shift-share analysis shows that rising in unemployment in the decade prior to the current crisis did not reflect composition effects, such as a growing share of young, less educated and/or black Africans, but instead the growing incidence of unemployment within these groups (Figure 8); demographic shifts have in fact been largely neutral overall. This points to an increasingly dysfunctional labor market that fails to create enough jobs for both labor market entrants and workers who lose their jobs due to competition and automation. 
Figure 8: Shift-share analysis of unemployment in South Africa

Decomposition of unemployment rate increase (by age, 2008-2019)

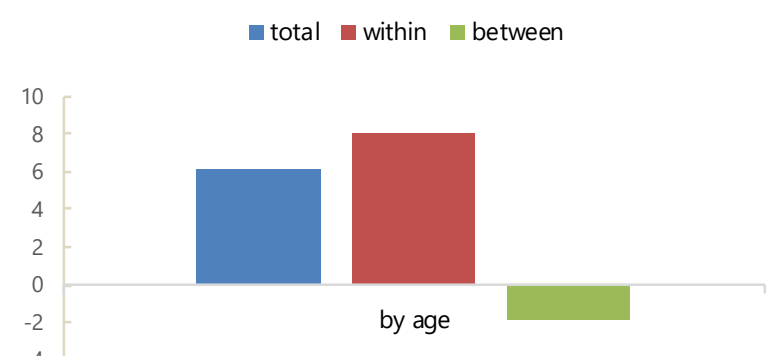

Decomposition of unemployment rate increase (by education , 2008-2019)

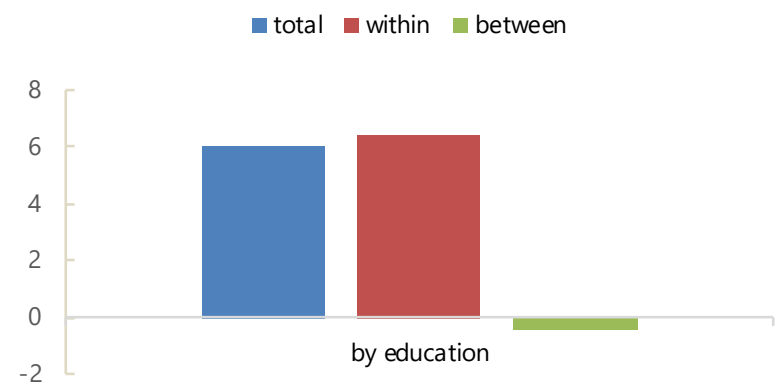

Decomposition of unemployment rate increase (by population group, 2000-2019)

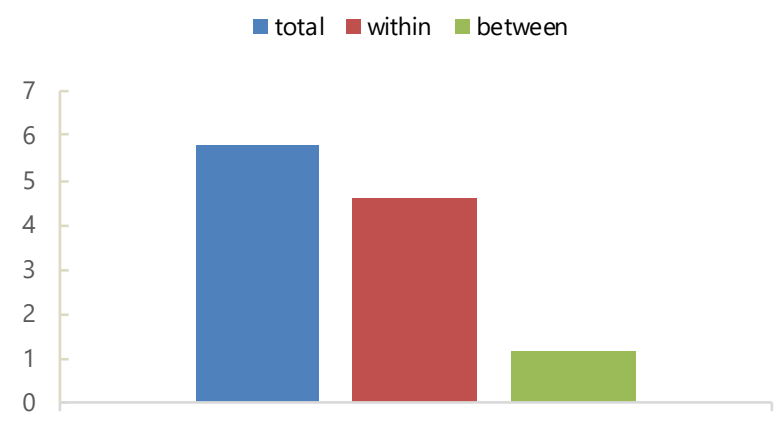

by population group
Within-group change in unemployment rate (by age, 2008-2019)

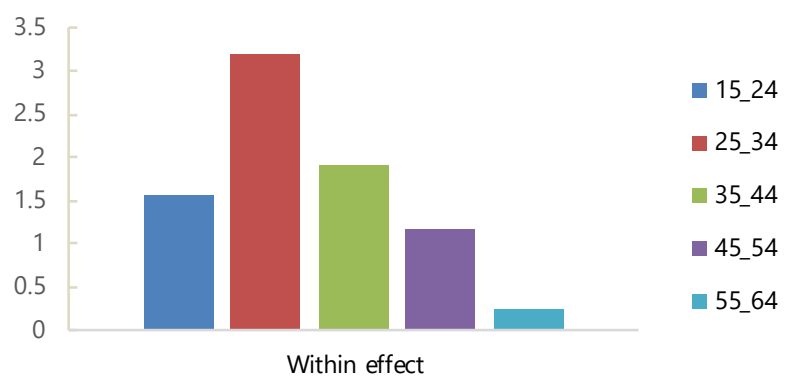

Within-group change in unemployment rate (by education , 2008-2019)

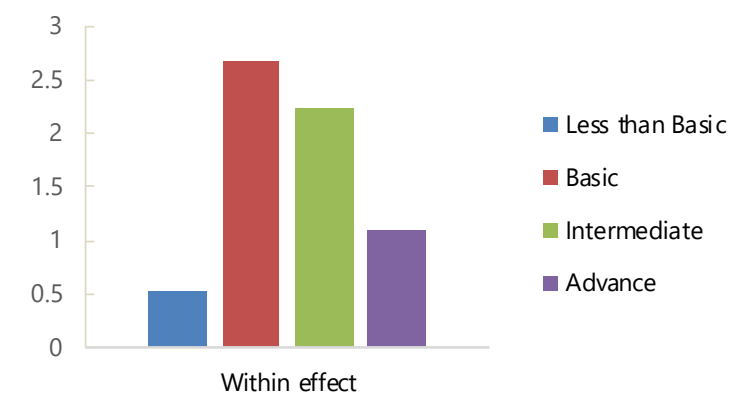

Within-group change in unemployment rate (by population group, 2000-2019)

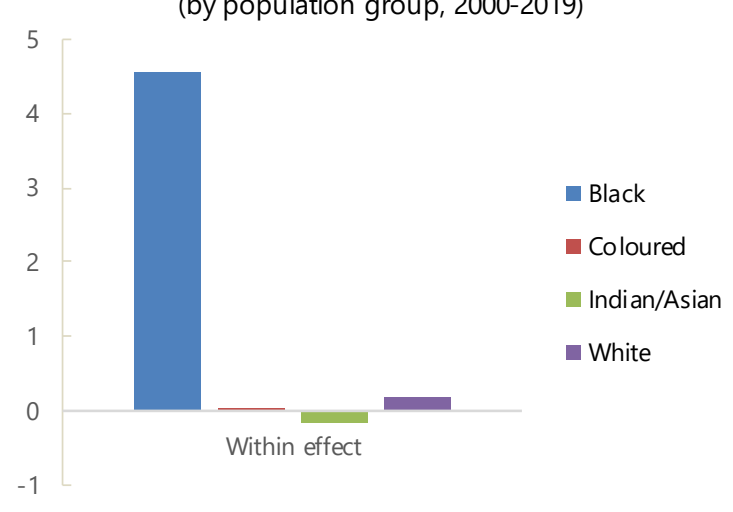

Source: South Africa Statistics LFS (2000-2007), QLFS (2008-2019); ILO STAT; IMF staff calculations.

Note: Decompositions rely on a shift-share analysis of unemployment rates by age/education/population group starting from 2008 (from 2000 by population group):

$$
\Delta U R_{t}=\sum_{i} \omega_{i, t-1} * \Delta U R_{i, t}+\sum_{i} U R_{i, t-1} * \Delta \omega_{i, t}
$$

where UR denotes unemployment rate in a given year and $\omega_{i}$ is the share of labor force population in demographic group i. The first and second terms of the right-hand side of equation represent the within- and between-group components of changes in the aggregate unemployment rate in South Africa, respectively. Results are cumulated over years to show the effects from 2008 to 2019.

13. Overall, these trends underscore both the urgency of policy action and the need for it to enhance the job prospects of disadvantaged groups. This is the main underlying — and, for youth, explicit (see section "Lifting Youth Job Prospects") —focus of the rest of this paper. 


\section{IMPROVING THE FUNCTIONING OF KEY LABOR MARKET INSTITUTIONS}

\section{A. Wage bargaining and minimum wages}

\section{Key features of wage bargaining and minimum wages in South Africa}

14. South Africa's has multi-faceted bargaining system that combines industry- and firm-level bargaining, supplemented with minimum standards in some sectors. Through unions, workers in South Africa can bargain with employers in two main ways, both on a voluntary basis: i) at industry-region level with associations of employers, thereby forming so-called "bargaining councils", as codified by the 1995 Labour Relations Act (LRA); ii) at the plant level. This results in a mixed system where both industry- and plant-level agreements co-exist and overlap — when they do, plant-level agreements typically raise worker pay above the level mandated by the centralized agreement. In those industries where unions are under-represented - and therefore collective bargaining is unlikely to take placeand workers are at high risk of getting low pay, such as the wholesale and retail sector or domestic services, the 1997 Basic Conditions of Employment Act (BCEA) has been providing a set of minimum standards - so-called sectoral determinations — for wages and work conditions.

15. The recently introduced minimum wage will also significantly shape wage setting in South Africa, although the magnitude of this impact is still unclear and will vary across industries. Since the November 2018 National Minimum Wage Act (NMWA), a national minimum wage (of R20.76 per hour from 1 March 2020, with sub-minimum wages for agricultural and domestic workers, as well as temporary exemptions - for up to a yearin principle) takes precedence over any collective bargaining agreement or sectoral determination. The minimum wage will be most binding - and thereby will most reduce inwork poverty but also possibly low-skilled employment - in those industries that are covered by sectoral determinations, since its level stands above the prevailing median wage in most of these industries (National Minimum Wage Panel, 2016). Because this gap would have been largest in agriculture and domestic services, sub-minimum wages were adopted for these industries. How the national minimum wage will affect the bargaining council system is a more open question, given that median wage levels set by collective agreements had exceeded the new minimum wage already before the latter was introduced.

16. Industry-level bargaining has significant worker coverage, although with wide variation across industries. The coverage of bargaining councils, namely the share of all employees covered by an ind ustry-region agreement, has traditionally been high - in the order of one-third to two-thirds - in manufacturing - where it was close to two-thirds overall 
in 2013/2014, mining, transport and storage, and the public sector. Coverage has been much lower in other industries, and below 15 percent in the private sector and 25 percent overall (see e.g. Godfrey, 2018). These patterns partly recoup those of union membership; while total union density, namely union membership as a share of employed workers, now stands at around 27 percent (Figure 9 and Visser, 2019), it has long been much higher in transport and storage, manufacturing and, especially, mining (see e.g. Budlender, 2009). In addition, the coverage of bargaining council agreements is increased to all employers and workers within the relevant industry in through administrative extensions of the agreement's provisions to non-signatory parties. Such administrative extensions are granted by the Minister of Labour if the agreement is deemed to be "sufficiently representative". In practice, extensions raise the coverage of agreements quite significantly in some industries - by 50 percent in manufacturing, for example (Godfrey, 2018). However, their overall impact is more modest because they do not play any role in the public sector and industries with bargaining council agreements account for a limited share of private sector workers; the overall union coverage rate, namely the share of employed workers who are covered by collective bargaining agreements, may be close to 30 percent, about 2 to 3 percentage points above the union density rate (Figure 9). Finally, beyond collective bargaining, sectoral determinations also have significant coverage - the share of employees they cover has been put at over a third (Godfrey and others, 2006; Godfrey, 2018).

\section{Challenges}

\section{Well-designed collective bargaining systems can support inclusive growth.} Collective bargaining can improve job quality by delivering otherwise underprovided local public goods (such as occupational safety and health, or the prevention of workplace abuse), and reduce inequality between workers by compressing wage schedules (see, for example, Freeman 2010; Jaumotte and Osorio-Buitron 2015; and, for a broad overview and recent evidence, OECD, 2019). Collective bargaining can also improve productivity through various means; for example, by strengthening the functioning of internal labor markets, addressing other market failures (such as employers' inability to appropriate the returns from investments in their workers' general training) and, more broadly, by giving workers a voice in work organization (see e.g. Freeman and Medoff, 1984). Finally, a well-functioning bargaining system may also dampen the employment effects of macroeconomic shocks by facilitating wage adjustment (IMF, 2016; OECD, 2019). 


\section{However, international experience indicates that several demanding} requirements need to be met for collective bargaining systems to deliver high and stable employment. To this end, collective bargaining system needs to deliver both macroflexibility - the ability to maintain employment at a high level in the face of large economic shocks such as major recessions - and microflexibility - the ability to (re)allocate workers to the most productive jobs across firms and industries (Blanchard, Jaumotte and Loungani, 2013). International experience points to two groups of countries that have succeeded in achieving these - those with decentralized bargaining, and those with more centralized bargaining but with the following key ingredients (see also Table 1 for a simplified taxonomy of collective bargaining systems):

- $\quad$ Strong bargaining coordination. Highly coordinated bargaining systems can be conducive to low unemployment (OECD, 2019). This is because when unions coordinate their actions, and employers coordinate theirs, they have an incentive to internalize the adverse effects of high wage claims on economy-wide employment and inflation (e.g. Calmfors and Driffill 1988). Indeed, looking across those advanced economies where collective bargaining plays an important role in wage determination, unemployment has been typically lower and more stable where bargaining is highly coordinated at the industry-level (Austria, Germany, Japan, Netherlands, Scandinavian countries) than in countries with uncoordinated industry level bargaining (Southern European countries).

- $\quad$ Firm-level flexibility. Beyond coordination, successful sector-level bargaining systems have typically allowed for some degree of firm-level flexibility. For example, unlike Portugal and Spain until the 2010-2012 euro area crisis, Germany introduced already in the 1990s so-called opening clauses, which allow firms facing hardship to set less favorable wages and working conditions than those in the applicable sectorlevel agreement - a feature that has been credited for the resilience of the German labor market during the 2008-2009 global financial crisis (Dustmann and others 2014). Opt-out clauses are a way for sector-level bargaining to deliver the microflexibility that firm-level bargaining achieves by design (Jimeno and Thomas, 2013).

- $\quad$ Representativeness of bargaining parties. In sector-level bargaining, representative bargaining parties are more likely to set wage levels and working conditions that are suitable for the average firm and worker in the sector. In particular, since small and medium-sized enterprises (SMEs) are generally less productive and more vulnerable to shocks than larger firms, it is important that they be actively represented at the bargaining table. For this reason, Several Southern European countries tightened representativeness criteria - raising minimum thresholds for sector-level agreements to come into force-in the wake of the 2010-2012 euro area crisis. 
- Administrative extensions. Administrative extensions of collective agreementsunder which a sector-level agreement signed by a subset of employer and employee representatives is typically extended to all workers in the sector-can reduce bargaining costs and avoid a "race to the bottom" among firms on working conditions. However, by design, they undermine firm-level flexibility by imposing similar working conditions across firms. There is mounting empirical evidence of adverse employment effects of administrative extensions (Diez-Catalan and Villanueva 2015; Hijzen and Martins 2016; Martins 2014), including in South Africa (Magruder, 2012). Adverse effects are also more likely when the original agreement is not representative - if it was negotiated by larger firms and is not suitable for SMEs, for example. Therefore, any use of extensions should ensure that extended provisions do not harm a significant fraction of firms. This can be achieved by extending only agreements that meet stringent union and employer association representativeness criteria (Hijzen and Martins 2016). Retaining discretionary power from Authorities on the extension decision, to be used when rapid macroeconomic adjustment is needed, also helps.

- $\quad$ Trust between social partners. High trust between social partners has been associated with higher employment and smoother adjustment to shocks, including after the GFC (Blanchard and Philippon, 2004; IMF 2016). This is likely because, when employers are hit by adverse economic shocks, trust makes workers more willing to make difficult compromises that will end up preserving jobs.

\begin{tabular}{|c|c|c|}
\hline \multicolumn{2}{|c|}{ Table 1: A (very) simplified taxonomy of collective bargaining systems around the world } \\
\hline & $\begin{array}{c}\text { Decentralized } \\
\text { (firm) }\end{array}$ & $\begin{array}{c}\text { Centralized } \\
\text { (industry/region/national) }\end{array}$ \\
\hline $\begin{array}{c}\text { Higher representativeness, } \\
\text { coordination, and firm- } \\
\text { level flexibility }\end{array}$ & N/A Northern EU countries \\
\hline $\begin{array}{c}\text { Lower representativeness, } \\
\text { coordination, and firm- } \\
\text { level flexibility }\end{array}$ & $\begin{array}{c}\text { English-speaking AEs } \\
\text { Baltic countries } \\
\text { Most EMDEs }\end{array}$ & $\begin{array}{c}\text { Southern EU countries } \\
\text { Argentina } \\
\text { South Africa }\end{array}$ \\
\hline
\end{tabular}

Source: IMF staff based on raw information in Visser (2019).

19. These conditions do not appear to be met in South Africa, pointing to the need for reform-particularly to foster greater firm-level flexibility, at a time when firms are hit differently by the ongoing economic downturn: 
- Degree of coordination. South Africa's bargaining system is not coordinated, since there is no coordination between different bargaining councils or their members (Figure 10). This implies that bargaining parties lack incentives to factor in the potential adverse economy-wide effects on employment and inflation of their (industry-level) wage decisions.

\section{- $\quad$ Representativeness of bargaining parties.}

While the LRA requires that trade unions and employers' organizations be "sufficiently

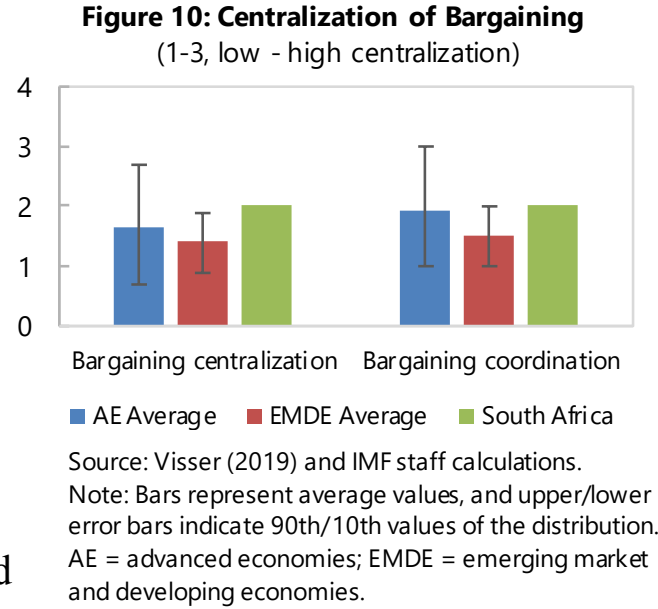
representative" for the Minister of Labour (after consultation with the National Economic Development and Labour Council (NEDLAC)) to approve the establishment of a bargaining council, there is no hard criterion in practice, leaving important room for discretion. This has been a source of contention among, and litigation from, small and medium-size enterprises (SMEs). Indeed, while the law requires adequate representation of SMEs, no proof of actual representation is needed in practice (Godfrey, 2018). Declining trade union membersh ip (from close to 40 percent in 2000 to about 27 percent in 2015) is putting growing pressure on the representativity of bargaining councils - and on the administrative extension of agreements, which is discussed next. Insufficient representativeness makes it more likely that negotiated industry-level wage conditions be inadequate for a significant fraction of firms, notably SMEs.

- $\quad$ Administrative extensions. This risk is further strengthened by the process for administrative extensions. While an administrative extension to non-parties to the agreement is subject to clear quantitative criteria, these do not include any requirement that a majority of employers be covered —only a requirement that signatory employers employ a majority of employees, and that a majority of employees be members of the signatory trade unions. This, together with the limited representativity of industry-level agreements in the first place, weakens the ability of SMEs to compete with larger firms in these industries, and to adjust to adverse economic shocks — such as Covid-19- that may warrant renegotiating work conditions with employees in order to save jobs. In addition, despite the efforts of some bargaining councils, in general neither the agreements nor their extensions cover non-standard forms of employment such as, for example, independent contractors or temporary employment services, which have been on the rise in South 
Africa over the last two decades - partly as a way to circumvent bargaining council agreements, with adverse implications for job quality and inclusiveness. ${ }^{4}$

- $\quad$ Firm-level flexibility. Individual firms cannot readily opt out of an industry-level agreement in case of hardship, further hampering their ability to adjust to adverse shocks without cutting jobs. However, (both signatory and non-signatory) firms can, and do regularly apply for exemptions, which are often granted by the bargaining councils themselves - Godfrey (2018) reports a success rate of over 80 percent, although it is unclear whether applications from distressed firms that would significantly undercut industry-level wage levels would succeed.

- $\quad$ Trust between social partners. Collective bargaining in South Africa has been consistently adversarial, as reflected by high (and rising) strike activity, against the background of conflictual labor relations between employers and workers (Figures 11 and 12).

Figure 11: Industrial disputes (working days lost per 1000 employees)

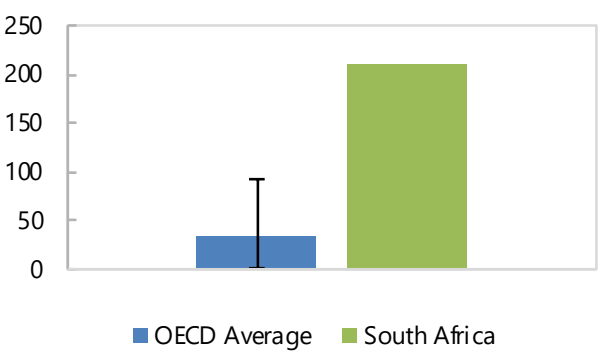

Source: OECD (2017), South Africa Department of Employment and Labor (2018).

Note: The figure shows average annual working days lost per 1000 salaried employees. Bars represent average values, and upper/lower error bars indicate 90 th/10th percentiles of the distribution.

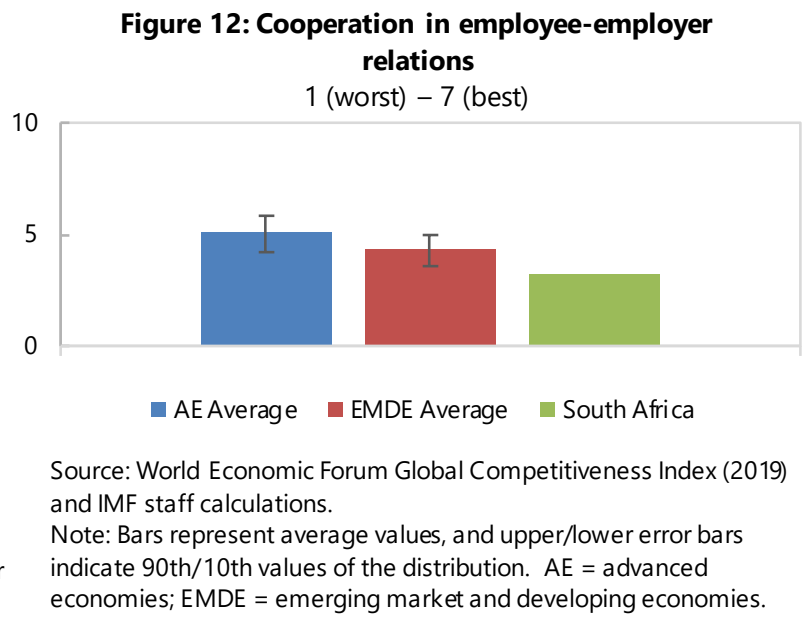

- Wage moderation (or lack thereof). Some of these features of South Africa's wage bargaining system are not conducive to overall wage moderation and high employment. Consistent with this, union wage premia - the wage gain from being a union member, all else equal-have been high in South Africa, in the order of one fourth on average (OECD, 2008).

\section{The minimum wage is high in international comparison, raising further} challenges for SMEs and making it more difficult for disadvantaged workers to find and retain regular jobs. At about 90 percent (of median formal worker wages - and 100 percent of the median wage across all workers), the minimum-to-median wage ratio is much

\footnotetext{
${ }^{4}$ Furthermore, while amendments to the LRA in 2002 and 2014 have sought to bring clarity, the extension process has been cumbersome and prone to legal challenge For example, the National Employers' Association of South Africa (NEASA), which represents primarily SMEs across various industries, has challenged the extension of the Metal and Engineering Industry Bargaining Council's (MEIBC) agreements. Likewise, the Free Market Foundation raised a constitutional case against extensions, which was brought down by the High Court in 2016.
} 
higher than in any OECD country, and one of the highest among EMDEs (Figure 13). In part, this reflects lower absolute median wages, which require that the minimum wage be set at a high relative level to fulfill its antipoverty objective. While the evidence suggests that minimum wages have likely had only small effects on overall employment at levels that have historically prevailed in most countries, it also indicates that, if set too high, minimum wages undermine the job prospects of disadvantaged groups in the labor market - including, among others, youth, as cross-country individuallevel empirical evidence further below indicates. ${ }^{5}$ To mitigate this risk, a number of OECD countries apply lower minimum wages to less productive categories of workers, including youth. In South Africa,

Figure13: Minimum-to-median wage ratios

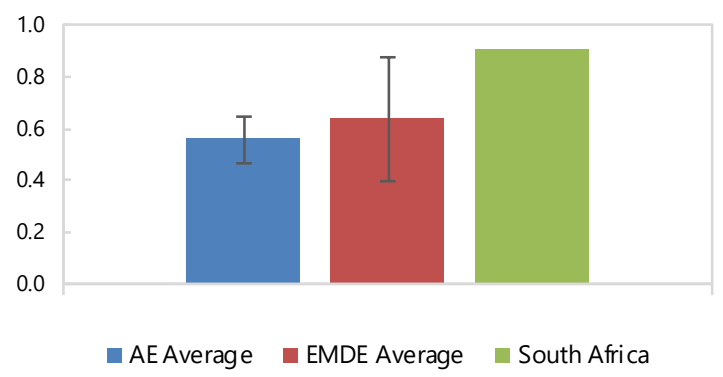

Source: ILO STAT, South Africa Statistics and IMF staff calculations. Note: Bars represent average values, and upper/lower error bars indicate 90 th/10th values of the distribution. The ratio of South Africa is calculated as nominal minimum wage over median wage of formal sectors, both data coming from South Africa Statistics. AE = advanced economies; $\mathrm{EMDE}=$ emerging market and developing economies. sub-minimum wages only exist for farm and domestic workers, as well as for workers employed on public works programs. ${ }^{6}$

\section{Options for reform}

\section{Collective bargaining reform should either aim to enhance coordination between social partners or, if too challenging, decentralize bargaining at the firm level altogether. International experience suggests that coordinated bargaining would strengthen} the responsiveness of labor costs to macroeconomic conditions and raise average employment. There is scope for strengthening coordination, such as by adopting a norm that facilitates negotiation (inflation, productivity gains or a combination of the two), and having the government highlight more prominently in the process the employment costs of excessive wage growth - as has been the case in a number of successful northern European economies. However, it might be challenging to generate the high trust between employers and workers that underpins the smooth functioning of coordinated bargaining in these economies, which is rooted in decades of practice. ${ }^{7}$ While trust is hard to engineer, frequent negotiations

\footnotetext{
${ }^{5}$ For example, Ahn et al. (2019) exploit cross-province cross-time variation in minimum wages in Indonesia-where minimumto-median wage ratios are comparable to South Africa's—and find sizable adverse effects on youth employment and, to a lesser extent, on aggregate employment. Evidence from South Africa itself points to a sizeable negative employment impactmostly through reduced job creation —of the large increase in sectoral determinations covering farmworkers in 2013 (Piek, von Fintel and Kirsten, 2020). For a review and lessons for the design of minimum wages (and other labor market institutions) in emerging market economies, see Duval and Loungani (2019).

${ }^{6}$ Workers who have concluded learnership agreements are not subject to the national minimum wage, however, as they receive learnership allowances instead.

${ }^{7}$ Greater trust among social partners could also reduce the length (and thereby the cost) of strikes. So might strike ballots, whose reintroduction was featured in the initial amendments to the LRA in 2012, but was eventually dropped.
} 
between social partners can help over time (see e.g. Hijzen, Martins and Parlevliet, 2017). Should fostering coordination and trust prove too difficult especially in the near term, the alternative is to decentralize bargaining at the firm level altogether.

22. In any event, collective bargaining should be more representative of all types of firms and workers and allow for greater flexibility at the firm level - two features of many successful (coordinated) industry-level bargaining systems in advanced economies. This can be achieved through:

- Introducing opt-out clauses in collective agreements, with clear criteria for opting out - which should be based on whether the firm requesting an opt-out faces hardship.

- $\quad$ Stronger representativeness of bargaining councils, by setting and enforcing clear quantitative criteria for whether they are "sufficiently representative". One such criterion could be that bargaining parties must represent the majority of employees and employers in the industry for a bargaining council to be established. This, in turn, requires detailed and reliable firm-level employment data within each industry.

- Additional criteria for administrative extensions of collective agreements, such as a requirement that signatory employers' organizations represent at least the majority of the total number of employers. This would incidentally strengthen incentives for employers' organizations to bring in more SMEs. In addition, conditional on all criteria being met, the Minister could retain some discretionary power and decide to grant an extension based on a meaningful test of public interest (as is the case in a country like the Netherlands, for example — for related IMF work, see Hijzen, Martins and Parlevliet, 2017).

\section{Model-based analysis confirms that greater firm-level flexibility in wage} bargaining could make a dent into high structural unemployment. To analyze the impact of alternative wage bargaining systems on job flows and unemployment, a model with (search and matching) labor market frictions is calibrated to the South African economy (see Appendix I for details). In this model, individual firms are hit by productivity shocks, whose distribution is calibrated on South African data. For example, this captures the fact that a shock such as Covid-19 is hitting different firms differently. Under wage bargaining at the individual firm level, wages fully adjust (downward and upward) to firm-specific shocks, while under sector-level bargaining wages can only accommodate sector-wide productivity shifts, but not heterogeneity across firms within each sector. As a result, sector-level bargaining leads to more job destruction and less job creation than firm-level bargaining, on average, resulting in higher average unemployment. Once accounting for the fact that sectorlevel bargaining covers only about a quarter of employees, model simulations imply that applying flexible opening clauses that enable individual firms to adjust wages and/or hours 
when facing hardship (a negative shock) could cut overall structural unemployment by about 2 percentage points (Figure 14).

24. These gains would be much amplified if sectoral determinations and national minimum wage setting also made it possible to adjust individual firm wages when needed in those industries not covered by sector-level bargaining. Minimum wage determination should remain flexible and put due emphasis on the job prospects of disadvantaged groups. Chapter 2 of the NMW Act of 2018 states that the annual review conducted by the NMW Commission should promote reduced poverty and wage differentials, while considering a range of factors including inflation, productivity and the operation of small firms, among others. While employment is not explicitly mentioned, it should play a central role in practice, both as a goal-being a major driver of poverty and income inequality - and as a consideration. In particular, the review should be informed by regular, rigorous and independent evaluations of the NMW's effects on the job prospects of disadvantaged groups in the labor market. Reflecting this, the Commission should also feel free to recommend, and the government to consider both upward and downward NMW adjustments depending on those job prospects, as well as overall macroeconomic conditions - including, importantly, aggregate productivity growth. While inflation rightly feeds into the review, any de facto indexation of the NMW should be avoided for NMW setting to retain the flexibility needed to smooth the employment effects of macroeconomic shocks - both directly, and indirectly by easing the output-inflation trade off faced by the SARB. Finally, some consideration could be given to introducing sub-minimum wages for particular categories of workers, primarily youth - particularly if the minimum-to-average ratio remained close to its currently high level in the coming years.

25. Over the medium term, as fiscal space is restored, in-work tax credits targeted at low incomes could be introduced alongside minimum wage moderation. This approach, which combines ramping up in-work tax credits to boost low-skilled workers' incomes while keeping the minimum wage moderate to maintain strong employment prospects, has been followed by a number of AEs to meet both employment and in-work poverty objectives in the last three decades. Overall, results have been encouraging in terms of both low-skilled job creation and in-work poverty reduction (see e.g. OECD, 2018). In the case of South Africa, greater reliance on in-work tax credits to boost low-skilled worker incomes would ease the burden on the NMW and thereby support job creation. 


\section{B. Employment protection legislation and enforcement}

\section{Key features and challenges}

\section{Employment protection legislation (EPL) provides important legal protection} against discrimination, but the obstacles it puts to economic layoffs should be kept moderate, simple and efficiently enforced. Legal protection against layoffs for noneconomic motives, which can involve abuse and discrimination, is critical and particularly valuable for workers un- or under-protected by unions due to limited bargaining coverage. Whether, and if so how EPL should also address dismissal for economic reasons should be the main policy focus given the multiple, well-documented - albeit generally moderate - costs of stringent EPL including: i) weaker productivity and output per capita; ii), reduced flows in and out, and thereby longer duration of unemployment; and iii) greater labor market dualism, as strict EPL typically strengthens the job stability of prime-age male workers while making it more difficult for disadvantaged workers (such as youth or the low skilled) to find regular jobs and increasing their job turnover (for a more detailed discussion, see Duval and Loungani, 2019). In addition, a well-functioning unemployment insurance (UI) system is a more efficient way to protect workers against the income loss risk from being laid off. ${ }^{8} \mathrm{~A}$ consensus is emerging that legal protection against economic layoffs should generally be kept moderate, simple — relying on (moderate) severance pay rather than cumbersome dismissal procedures - and efficiently enforced - with a low frequency of judicial procedures that are kept short and yield reasonably predictable outcomes.

Accordingly, most reforming countries in the last two decades, including many advanced economies after the GFC, have sought to ease EPL for regular workers, simplify layoff procedures, and improve enforcement - by facilitating negotiated (out-of-court) settlements, shortening judicial procedures, and capping the amount of severance pay awarded by courts or no longer allowing reinstatement (see e.g. Duval et al., 2018).

27. While EPL is not particularly tight de jure in South Africa, its enforcement is burdensome and slow, creating undue uncertainty. Existing ILO or OECD indicators of the stringency of EPL point to rather moderate obstacles to individual and collective dismissals of regular workers,

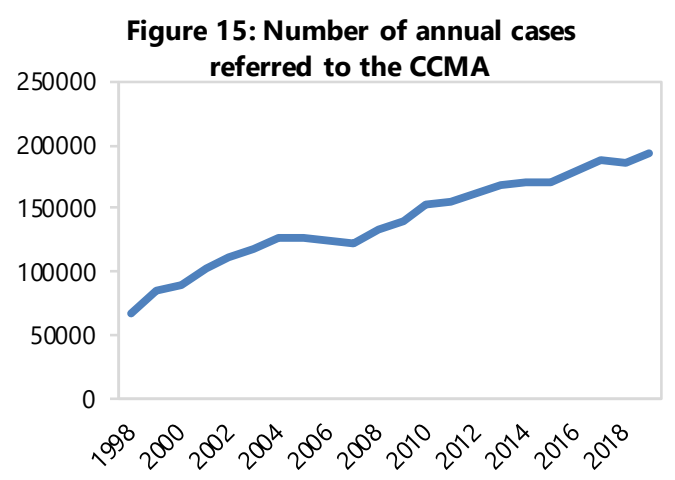

Source: 2018/2019 CCMA Annual Report.

\footnotetext{
${ }^{8}$ In addition to the economic costs listed above, EPL suffers from two weaknesses relative to UI: i) being a one-off payment to the worker, severance pay provides no insurance against the risk of staying unemployed for long; and ii) it offers no risk sharing across workers in different firms, which, coupled with a lack of prefunding, increases the risk of nonpayment. Further, many workers may not qualify owing to short tenure, or are not covered owing to informality. Finally, the growing fragmentation of the world of labor work calls for portable rights across different contractual forms of work (permanent contract, temporary contract, temporary agency work, self-employed...etc) — that is, for protecting workers (through UI) rather than jobs (through EPL) (IMF, 2018).
} 
while EPL for temporary workers is rather flexible. ${ }^{9}$ However, these indicators significantly under-estimate the stringency of EPL, because they do not capture key features of enforcement, notably the extensive dispute resolution process. The institutions for dispute resolution include the Commission for Conciliation, Mediation and Arbitration (the CCMA) and the Labour Courts (the Labour Court and the Labour Appeal Court). In all cases, disputes go through a conciliation procedure before they can proceed to arbitration (CCMA) or adjudication (Labour Courts). These processes are burdensome and can easily take several years to go through. Further, their outcome can vary widely, creating costly uncertainty for employers and employees:

- $\quad$ Procedures are numerous and lengthy. Over 193000 cases (including conciliations) were referred to the CCMA alone in 2018/201910_ over three times the annual caseload two decades ago (Figure 16), and six times the level the institution was originally set up to handle (Bhorat, Pauw and Mncube, 2009). This large caseload, together with the CCMA's own financial and human resource constraints, have contributed to lengthy resolution procedures - in some cases it can take well over a year after initial referral of the case to the CCMA for arbitrations to be completed (with an average of seven months, Bhorat and Stanwix, 2018). Once this process is complete, 10 to 15 percent of the CCMA's arbitration awards are subject to a further burdensome and lengthy judicial review by the Labour Court, whose decision can then be appealed to the Labour Appeal Court (Benjamin, 2013); a 24-months period for a review application to be heard in the Labour court, and a 12 to 24 months delay between the hearing and judgement dates at the Labour Appeal Court, are not uncommon (Benjamin, 2009), although more recent streamlining of Labour Court proceedings has reduced these delays.

- $\quad$ There is substantial uncertainty regarding the remedies. While the vast majority of cases are resolved through a financial settlement, employees are ultimately reinstated in a fraction of cases (about 13 per cent according to Benjamin, 2013) - saving the corresponding jobs as intended, but potentially making employers more selective upon recruiting, at the expense of disadvantaged groups of workers. When a financial settlement is involved, the CCMA may award any amount up to 12 months' remuneration as compensation, but the Labour Courts can only decide on whether compensation should be awarded, not on the amount; this has led them to award 12 months of compensation in most cases, even when the employer's lack of procedural compliance is minor (ILO, 2002).

\footnotetext{
${ }^{9}$ Incomplete compliance also weakens somewhat the practical reach of the law (Bhorat and Stanwix, 2018).

${ }^{10}$ See 2018/2019 Annual Report of the CCMA: https://www.ccma.org.za/About-Us/Reports-Plans/AnnualReports/Token/Viewlnfo/Itemld/39.
} 


\section{Options for reform}

28. EPL reform should focus on streamlining enforcement on several grounds. First, reducing caseloads would ease the burden on the CCMA and Labour Courts and thereby speed up resolution. Absent further resources, one option might be to encourage conciliation between the employer and laid-off workers at an earlier stage, for example; any such agreements, after a brief legal check by the CCMA, would come into force and could not be subject to any further procedure. Second, dispute resolution procedures should be shortened further. Simplifying or, if possible, even ending any Labour Court reviews of the CCMA's arbitration awards might help. Third, settlements should be made more predictable. One option here might be to forego any possibility of worker reinstatement. Also, to ensure that settlements are commensurate with employers' lack of compliance, Labour Courts could be allowed to finetune the amount of compensation, subject to a (possibly lower) ceiling. Such reforms would be similar in spirit to those carried out in many European countries, such as France, Italy, Portugal and Spain, in the last decade. The uncertainty involved in hiring staff could be further reduced, particularly for SMEs, if employment could be terminated without justification at the end of the probation period.

29. Streamlined EPL enforcement would not only support productivity and average income per capita, but could also reduce labor market dualism and thereby strengthen equity. Employers could become less hesitant to offer regular jobs, and rely less on temporary contracts including temporary employment services (so-called labor brokers), which have grown fast over the last two decades partly as firms sought to alleviate hiring and layoff costs, and pay lower wages and benefits than those mandated by bargaining councilsalthough these temporary employment services may gradually downsize following a 2014 LRA amendment and a 2018 ruling of the Constitutional Court that compel employers to insource after three months any employee who had been employed through labor brokers.

\section{The design and timing of EPL reform should factor in currently depressed labor} market conditions. Previous IMF work has shown that, in both advanced and emerging market economies, easing EPL pays off quickly in good times but can entail short-term losses when carried out in bad times (Duval, Furceri and Jalles, 2019; IMF, 2016, 2019). When the economy is depressed, firms respond to a relaxation of constraints on dismissals by dismissing rather than hiring more workers, thereby amplifying the labor market and broader economic downturn (Cacciatore and others, 2016). Therefore, EPL reform would be best enacted now but with a provision that it will come into force only later, for example in a year, when economic conditions are stronger. Alternatively, a reform could be grandfathered-that is, new rules and streamlined procedures would apply only to new beneficiaries; also for political economy reasons, this was the approach taken in a number of European countries after the 2008-2009 global financial and 2010-2012 euro area crises. 


\section{STRENGTHENING LABOR FORCE EMPLOYABILITY}

\section{While this paper focuses mainly on improving the functioning of key labor} market institutions, this should come hand in hand with reforms that increase returns to work for job seekers. Even with sound labor market institutions, returns to work could remain too low for many job seekers to move into employment. Returns to work are depressed by: the low education level of most of the labor force, which weakens productivity and prospective wages; low entrepreneurship, which further limits the range of high-value formal job opportunities; and the high side costs of performing jobs, notably high transportation costs, which reduce (net) take-home pay. While generally sound and key to mitigating the impact of the ongoing labor market downturn on incomes, social benefits might further weaken some job seekers' incentives to take-up jobs once the economy recovers. Boosting returns to work and employment requires a combination of procompetition product market reforms - particularly in transport, greater "activation" of social benefits, enhanced efficiency of education and apprenticeship schemes, and stronger entrepreneurship including through improved access to credit for SMEs. This section briefly covers key issues and policy options in each of these areas.

\section{Product market reform to raise employment and take-home pay}

\section{There remains much scope for product market deregulation to ease firm entry,} lower prices, increase purchasing power and increase returns to work (for a detailed discussion, see Thakoor, 2020). Easier product market regulation (PMR) reduces structural unemployment by encouraging firm and job creation while directly increasing worker purchasing power-which in turn can facilitate wage moderation and further employment gains. Recent micro evidence for South Africa indicates that, all else equal, employment is lower, and transitions from unemployment into employment

Figure 16: Stringency of product market regulations (0-6 scale from least to most stringent)

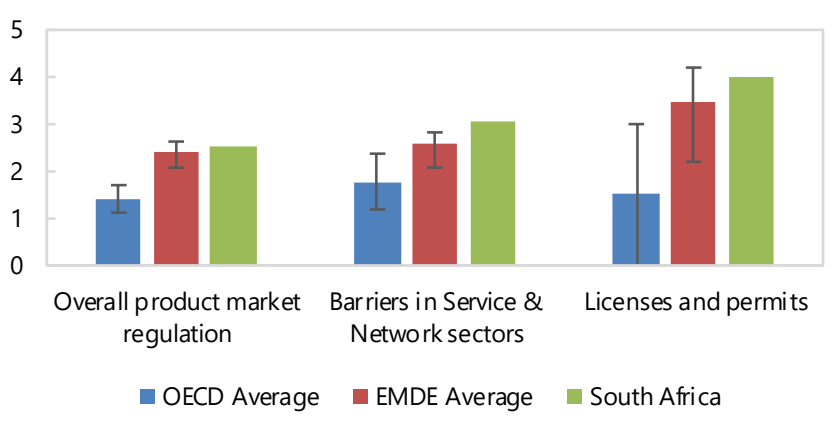

Source: OECD PMR database (2018) and IMF staff calculations. Note: Bars represent average values, and upper/lower error bars indicate 90th/10th values of the distribution. $\mathrm{AE}=$ advanced economies; $\mathrm{EMDE}=$ emerging market and developing economies.

are more difficult, in district municipalities where jobs are concentrated in high-markup industries (Amodio et al., 2020). In South Africa, wages are also lower in local labor markets where dominant employers hold power-so-called monopsony power (Bassier, 2019). IMF estimates imply that a product market reform package comparable in ambition to the average historical reform in AEs could not only boost productivity, but also cut structural unemployment by about one percentage point in the coming years (Bouis, Duval and Eugster, 2020; Duval and Furceri, 2018). In particular, there is scope for cutting 
administrative burdens on start-ups (licenses and permits) and barriers to competition in services and network industries, which are high even compared to EM peers (Figure 16).

33. Cutting commuting costs is especially important, given that transportation costs can devour up to a quarter of a typical low-skilled worker's wage (Ngarachu, Schimmelpfennig and Schöer, 2014); this would increase the financial return from taking up a job, foster wage moderation, and raise low-skilled worker's employment rates. It may also raise low-skilled workers' attachment to their jobs, employment duration and, ultimately, productivity (van der Merwe and Krygsman, 2020). Useful measures in this regard may include: assigning the management of rail and bus contracts to local governments in large cities to better integrate public transport and land use planning (National Treasury, 2019); targeting transport subsidies to low-wage earners; public investments in transport infrastructure and social housing to cut commuting time and costs.

\section{Entrepreneurship/SMEs financing}

\section{entrepreneurship and stimulate formal job creation. While South}

34. Strengthening SMEs' access to domestic finance could also help foster

Africa's financial markets are rather deep, most SMEs lack access to finance - under a third of them have a bank loan or a credit line, much less than in many other EMs (Figure 17).

Strengthening SMEs' access to domestic finance could help foster entrepreneurship and enable existing SMEs to scale up, stimulating formal job

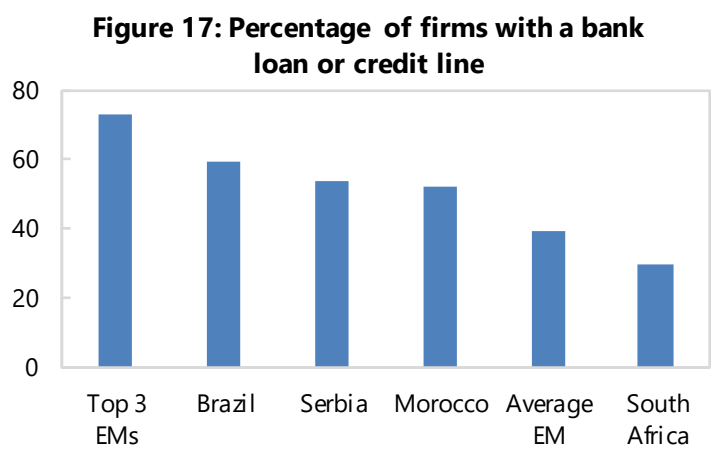

Source: World Bank Enterprise Surveys and IMF staff calculations. creation. To evaluate the longer-term effects of such reforms, a model with heterogeneous firms is built that captures important features of the South African economy, such as the coexistence of large formal firms and small informal firms, wide heterogeneity in productivity and size within each group, financial constraints in debt and equity markets that make it difficult for more productive formal firms to scale up, and large costs of entering the formal sector (for details, see IMF, 2019). Model simulations suggest that reforms to raise SMEs' access to credit to levels seen in most advanced emerging market peers - such that the overall corporate-debt-to-GDP ratio would rise from about 40 to 60 percent over the medium termcould raise GDP by about 3 percent and the share of formal workers in total employment by 6 percentage points. This is because greater access to finance would enable high-productivity credit-constrained SMEs to grow, and also stimulate the entry of new firms in the formal sector. Concrete reforms that could enhance SMEs' access to finance include easing barriers to entry in the banking sector, consolidating and simplifying government support to SMEs (e.g. through the Department of Small Business Development), targeting primarily younger 
and more dynamic firms, and creating one-stop shops for SMEs regarding regulation, taxation, and access to government support (see e.g. OECD, 2017).

\section{E. Social benefits}

35. South Africa's social benefits will help dampen the impact of the Covid shock on incomes and aggregate demand, but down the road there is scope for improving their design, most importantly by "activating" expenditures. Unemployment benefits and grants play a key role in insuring workers against the risk of income loss and alleviating poverty; as such, their temporary extension to help households cope with the fallout from Covid-19 is welcome and in line with broader IMF advice (IMF, 2020a,b). At the same time, benefit levels and design need to strike the right balance between providing an adequate safety net for those in need and maintaining strong work incentives. As regards benefit levels, available evidence for South Africa is generally inconclusive; for example, some studies have documented a negative impact of elderly grants on the labor force participation of prime-age men in recipient families (Bertrand, Mullainathan and Miller, 2003), while others find a positive effect on that of prime-age women as elderly recipients can take care of children (Edmonds, Mammen and Miller, 2005). As for design, international experience suggests some room for "activating" benefit recipients to boost their labor market integration - in practice, making some of the benefits conditional on, or rise with, hours worked. For example, a number of advanced economies have increasingly emphasized childcare subsidies over child support, in line with evidence that the former incentivize female participation (by increasing returns to work) while the latter discourage it (Guner, Kaygusuz and Ventura, 2020). Along similar lines, some consideration could also be given to shifting some of the spending on active labor market programs towards geographical mobility subsidies, which can ease spatial legacies behind high unemployment. Such measures should be considered only as the economy recovers and recent temporary grant extensions are rolled back.

\section{F. Education and apprenticeship}

36. Improving the quality and efficiency of education, apprenticeship and vocational training schemes would improve employability, raising both employment rates and wages. South Africa has made major progress on educational attainment in the last three decades, but basic education suffers from both low quality and high inequality, hurting employability and wages during adulthood. South Africa's average scores in international tests of scholastic achievement are both weaker and more unequal across students than those in other emerging economies (OECD, 2013). Insufficient supply of high-quality education also shows indirectly in very high private returns from schooling, notably at the tertiary level where they have been found to exceed 18 percent per year of schooling (Branson and Leibbrandt, 2013). Low education quality reflects both insufficient resources (infrastructure and equipment, number and quality of teachers, and their distribution across students) and cost inefficiencies. Given tight fiscal space, the immediate focus should be on efficiencyenhancing reforms, alongside more gradual, growth- and employment-friendly reallocation 
of public spending toward education. Priorities include strengthening school principals' management capacity and accountability, improving teacher monitoring and training, and easing credit constraints to enrollment in tertiary education (OECD, 2013). There is also scope for improving the quality and attractiveness of vocational education, including by strengthening staff's training and resources, and generalizing apprenticeship as part of the curriculum in vocational programs.

\section{LIFTING YOUTH JOB PROSPECTS}

37. Youth inactivity is stubbornly high. Only one in nine young people (aged 15-24) have a job (Figure 19). This would not necessarily be a concern if it reflected a conscious choice to attend education instead. However, half of the 15-24 year-olds seeking jobs are unemployed. And overall, about one-third of youth are neither in employment, nor in education or training (NEET), a disconcertingly high and stable share that puts South Africa among the worst EMDE performers (Figure 18).

Figure 18: Youth labor market performance
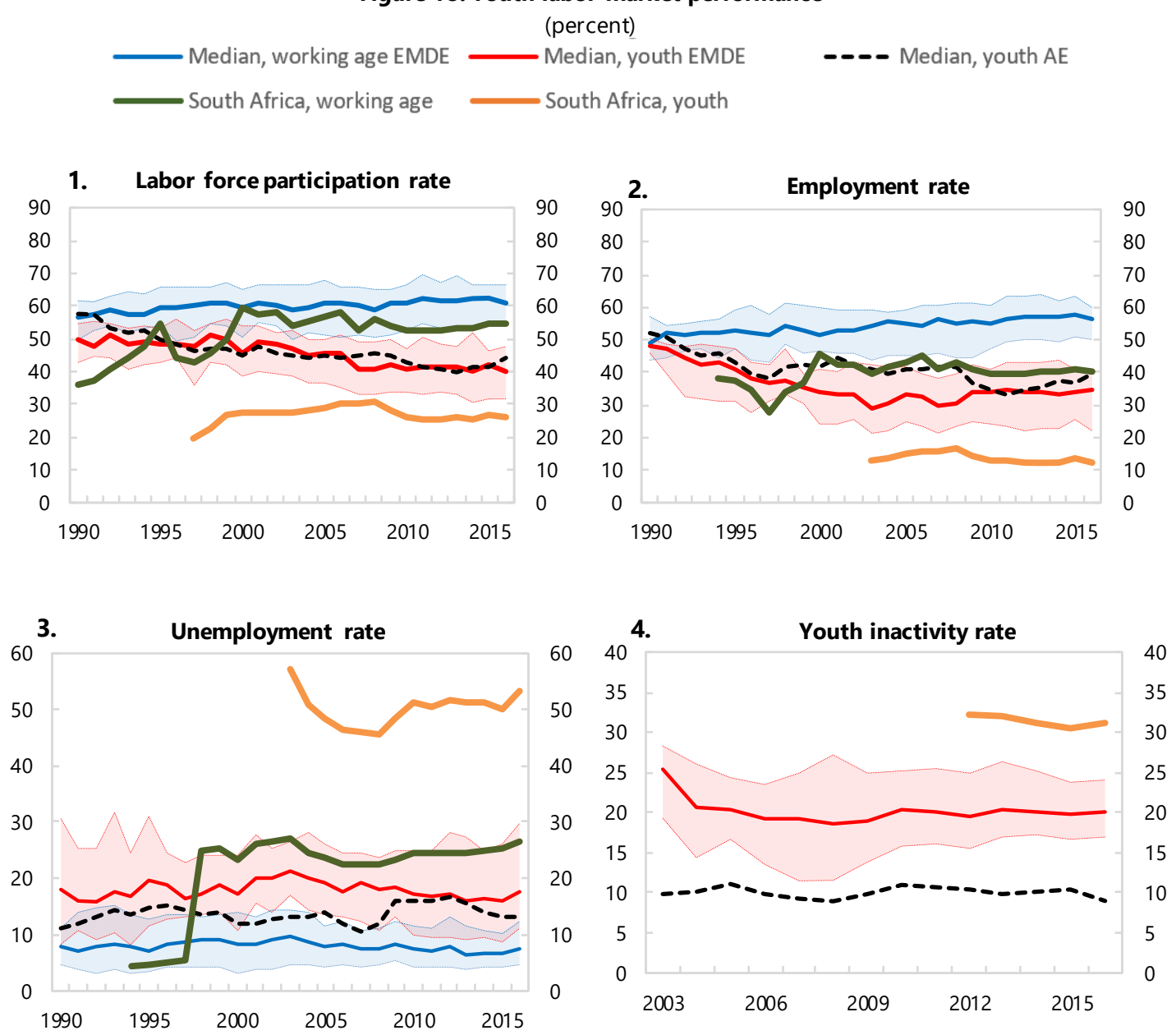

Sources: ILOSTAT Yearly Indicators; and IMF staff calculations.

Note: Labor force participation, employment rates, and you th inactivity rates are in percent of the relevant demographic group population. Youth inactivity rate is the share of youth those not in employment, education, or training (NEET rate). Un employment rates are in percent of the relevant demographic group labor force. The shaded and colored area around each line represents the 25 th to 75 th percentilerangefor that variable. Percentil es are calculated from the sample of countries in the indicated group. $\mathrm{AE}=$ advanced economies; $\mathrm{EMDE}=$ emerqing market and developing economies. 


\section{Young women are more penalized than young men, and are being hit harder by}

the current crisis. Empirical analysis using micro data spanning almost 90 million individuals and 47 countries points to a gender gap in youth (defined here as 15-29 year-olds) inactivity rates of over 10 percentage points in South Africa-below the EMDE average, but larger than in AEs (Figure 19). Through an individual probability model of labor market status, this youth inactivity gender gap can be further decomposed into two components (for technical details, see Ahn and others, 2019): i) differences in individual characteristics between young women and men (such as educational attainment, marital status, or having children); ii) differences in the impact of a given characteristic on the likelihood of being inactive. This analysis indicates that young women and men do not differ in key individual characteristics, but instead in the impact of these-for example, young women get more penalized in the labor market for having low education or having children. Indeed, having children increases young women's likelihood of being inactive by about 25 percentage points relative to young men, all else equal (Figure 19). This effect is comparable to that estimated in the average AE, and smaller than in EMDEs. As in many other advanced and emerging economies, there is also evidence that women are facing the largest employment losses from the ongoing crisis, partly because they occupy disproportionately contact-intensive jobs (Fabrizio, Malta and Mendes Tavares, 2020; Jain and others, 2020).

39. Youth employment rates correlate strongly with adult employment rates across countries, suggesting that policies that help the latter (disproportionately) help the former. This relationship is particularly tight for men, but also holds for women (Figure 20). South Africa's position behind the regression line indicates that even considering its very low adult employment rate, youth employment is still disproportionately weak in international comparison. This tentatively suggests that, as a complement to broad-based labor market 
reforms, targeted policies may also help raise youth employment rates - most importantly, as discussed above, improvements in education and apprenticeships, but also to some extent active labor market policies if well-designed.

Figure 20: Employment rates for youth and adults

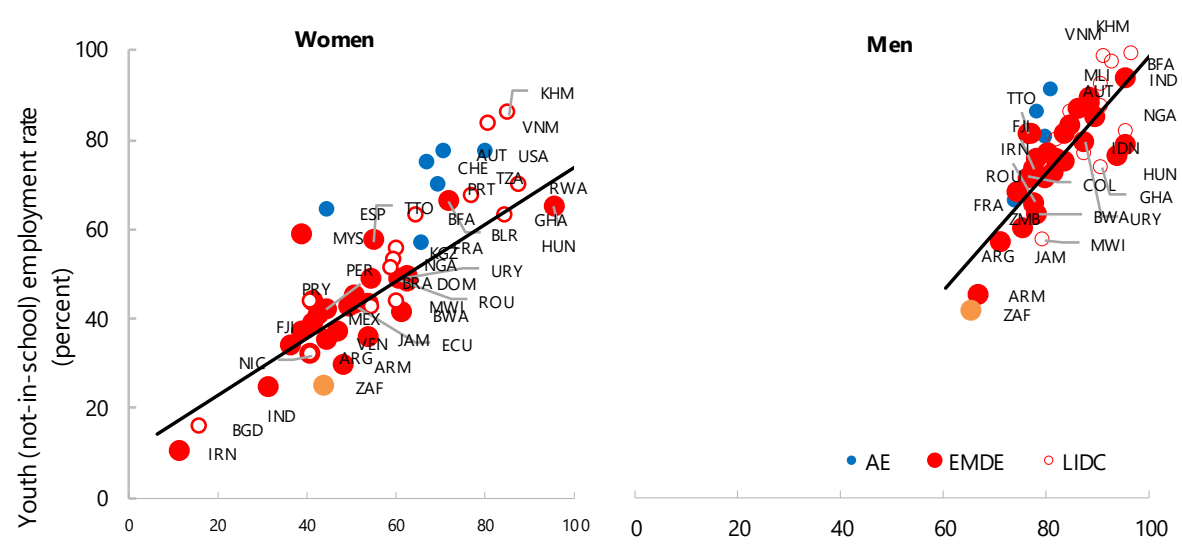

Adult employment rate (percent)

Sources: IPUMS International, and IMF staff calculations.

Note: Youth are 15-29 years old and adults are 30-64years old. Solid black line is line of best fit. AE = advanced economy; EMDE = emerging market and developing economy, non-LIDC; LIDC = low income emerging market and developing economy. ISO 3 -letter country codes are indicated for some data

\section{Cross-country individual-level analysis suggests that sub-minimum wages for} youth, easier EPL and PMR, and strong legal protection for women could help give youth more and better jobs. Economywide indicators of structural policies and other characteristics are introduced in the individual probability model to gauge their association with labor market status, with a particular focus, for each age and gender group, on the likelihood of being employed. ${ }^{11}$ The results suggest that lower minimum wages, easier EPL

Figure 21: Labor market effects of structural policies and characteristics (bar depicts change from South Africa's current polity setting to 25th percentile of the distribuion)

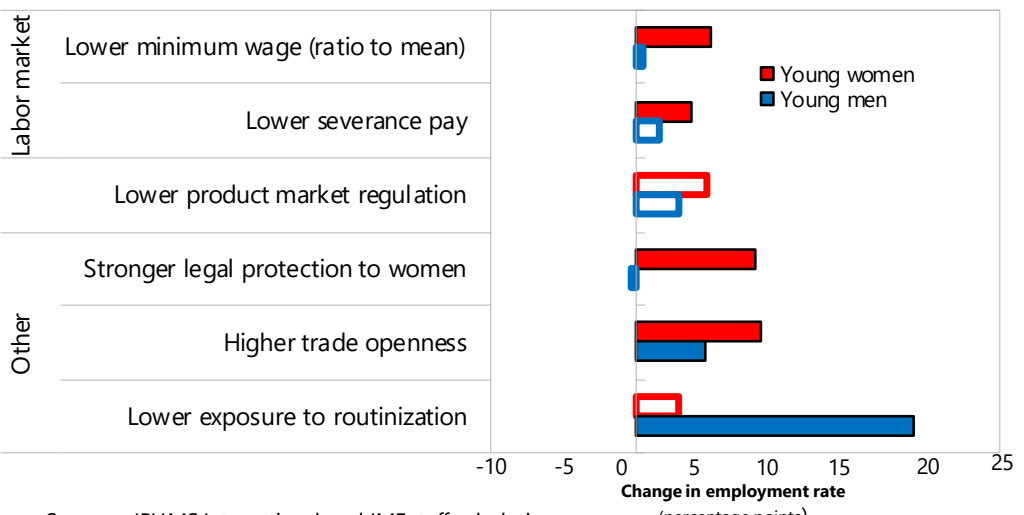

Sources: IPUMS International; and IMF staff calculations. (percentage points)

Note: the bars are calculated as (p25 - ZAF in dicator )*coefficient, which indicates the change in employment from changing from ZAF to a p25 policy indicator. Solid bars show the effects that are statistically significant at the 5 percent level for either young women or men are shown, while hollow bar show insianificant effects.

\footnotetext{
${ }^{11}$ Structural policy indicators and characteristics are considered one by one, while also accounting for a selected set of countrylevel variables such as GDP per capita. Sparsity of country and time-series coverage of these indicators limits the ability to jointly estimate the impacts of all potentially relevant structural policies and characteristics.
} 
and PMR - both domestically and externally through increased trade openness-all raise the likelihood that young people be employed (Figure 21). This holds particularly true among young women, in line with their more marginal status in labor markets. Easier EPL and PMR are also associated with higher youth job quality, as measured by a higher likelihood of obtaining a regular job contract (Figure 22). Some other economy-wide characteristics are found to matter too; in particular, the greater exposure of South Africa to routine jobs seems to be particularly detrimental to youth employment prospects - as indicated by the potential gains from a lower exposure, particularly for young men. Finally, young women's employment prospects could benefit from strengthening legal protections for women - particularly upon returning from maternity leave, and also at entry to alleviate risks of gender discrimination in hiring practices.

\section{Youth could also benefit from improvements in the design of active labor market policies (ALMPs), although these are no substitute to broad labor market reforms.}

- $\quad$ Several prominent youth ALMP programs exist in South Africa, including: the Expanded Public Works Programme (EPWP), which creates temporary work opportunities for youth in four public sectors; the National Youth Service Programme (NYSP), which includes youth development activities, technical and on -the-job practical training for one year; the Youth Employment Service (YES), a more recent joint initiative with the private sector to create one-year paid positions for youthwhich qualifies as an ALMP since recruiting employers benefit from the employment tax incentive (ETI) created in 2014.

- $\quad$ Recent randomized studies of youth ALMPs in South Africa highlight the need to act on general barriers to employment (notably EPL) and not to expect too much from ALMPs alone (Bertrand and Crepon, 2020; Levinsohn et al., 2014). Other evaluation studies also provided mixed results on the effectiveness of existing programs (see e.g. Aflagah 2020 on the ETI, or Meth 2011 on the EPWP). These mixed results are in line with broader research and meta-studies on the effectiveness of ALMPs in other countries (Card, Kluve and Weber, 2018; Crepon and Van den Bergh, 2016; McKenzie, 2017). Overall, there is an emerging consensus that ALMPs need to be very carefully designed to pass a cost-benefit analysis, and that many existing programs are not. 
- $\quad$ Nonetheless, at least two lessons from international experience with ALMPs are encouraging for South Africa. One lessons from AEs is that well-designed job search support and monitoring, integrated with benefit provision ("one-stop shops"), can help. One lesson from randomized studies in EMDEs is that geo graphical mobility subsidies can be effective - a promising finding in the South African context where many disadvantaged households do not live where the jobs are (McKenzie, 2017). Some of the more successful policy programs have provided assistance with learning about job opportunities in a different location (Jensen, 2012), or subsidizing job search in different parts of the city (Abebe et al. 2016 on Ethiopia; Bryan et al. 2014 on Bangladesh).

\title{
VI. CONCLUSION
}

\begin{abstract}
42. The fallout from COVID-19 has put further strain on South Africa's dysfunctional labor market. Cutting extreme unemployment has eluded South African policymakers for decades, and the ongoing crisis further raises the challenge. While there is no silver bullet, this paper argues, on the basis of new analytical work and a review of available evidence, that a multi-faceted approach that addresses jointly demand- and supplyside obstacles to job creation through bold institutional reforms could put South Africa's unemployment on a firm downward path and foster more inclusive growth. The prioritization, timing and sequencing of these reforms will have to factor in carefully the current macroeconomic context, notably very weak business cycle conditions and tight fiscal space. This puts a premium on starting with reforms that could deliver quick job gains under broad labor market slack at little or no budget cost. Prime candidates include the reforms of collective bargaining reform, product market regulation and-provided it were adopted now but came into force only later (or were grandfathered) - employment protection legislation and its enforcement discussed in this paper. Improvements in the design of ALMPs could also facilitate job reallocation, and thereby amplify the post-COVID jobs recovery.
\end{abstract}




\section{References}

Abebe, Girum, Stefano Caria, Marcel Fafchamps, Paolo Falco, Simon Franklin, Simon Quinn, and Forhad Shilpi. 2017. "Job Fairs: Matching Firms and Workers in a Field Experiment in Ethiopia." World Bank Policy Research Working Paper No. 8092.

Aflagah, Kodjo. 2020. "Failed Promises of a Wage Subsidy: Youth and South Africa's Employment Tax Incentive." Mimeo, University of Maryland.

Ahn, Jaebin, Zidong An, John Bluedorn, Gabriele Ciminelli, Zsoka Koczan, Davide Malacrino, Daniela Muhaj, and Patricia Neidlinger. 2019. "Work in Progress: Imporoving Youth Labor Market Outcomes in Emerging Market and Developing Economies." IMF Staff Discussion Note No.19/02, International Monetary Fund, Washington, DC.

Amodio, Francesco, Michele Di Maio, Yifan Li, and Patrizio Piraino. 2020. "Product Market Competition and the Labour Market - Evidence from South Africa." SA-TIED Working Paper No. 105. Southern Africa: Towards Inclusive Economic Development (SA-TIED).

Anand, Rahul, Siddarth Khotari and Naresh Kumar. 2016. "South Africa: Labor Market Dynamics and Inequality". IMF Working Paper No. 16/137.

Bassier, Ihsaan. 2019. "The Wage-Setting power of Firms: Rent Sharing and Monopsony in South Africa." SA-TIED Working Paper No. 105. Southern Africa: Towards Inclusive Economic Development (SA-TIED).

Benjamin, Paul. 2013. "Assessing South Africa's Commission for Conciliation, Mediation and Arbitration (CCMA)." ILO Dialogue Working Paper No. 47, Geneva.

Benjamin, Paul. 2009. "Conciliation, Arbitration and Enforcement: The CCMA's Achievements and Challenges." Industrial Law Journal (Juta) 30: 26-48.

Bertrand, Marianne, Sendhil Mullainathan and Douglas Miller. 2003. "Public Policy and Extended Families: Evidence from Pensions in South Africa." The World Bank Economic Review 17 (1): 27-50.

Bhorat, Haroon, Kalie Pauw and Liberty Mncube. 2009. "Understanding the Efficiency and Effectiveness of the Dispute Resolution System in South Africa: An Analysis of CCMA Data." Development Policy Research Unit Working Paper No. 09/137.

Bhorat, Haroon, and Benjamin Stanwix. 2018. "Wage Setting and Labor Regulatory Challenges in a Middle-Income Country Setting: The Case of South Africa." Background Note to World Bank (2018), An Incomplete Transition: Overcoming the Legacy of Exclusion in South Africa, Systematic Country Diagnostic: Republic of South Africa. 
Blanchard, Olivier, Florence Jaumotte, and Prakash Loungani. 2013. "Labor Market Policies and IMF Advice in Advanced Economies during the Great Recession." IMF Staff Discussion Note No.13/02, International Monetary Fund, Washington, DC.

Blanchard, Olivier and Thomas Philippon. 2004. "The Quality of Labor Relations and Unemployment." NBER Working Paper No.10590. National Bureau of Economic Research, Inc.

Bouis, Romain, Romain Duval and Johannes Eugster. 2020. "How Fast Does Prod uct Market Reform Pay Off? New Evidence from Non-Manufacturing Industry Deregulation in Advanced Economies." Journal of Comparative Economics 48(1): 198-217.

Bourlès, Renaud, and Gilbert Cette. 2007. "Trends in "Structural" Productivity Levels in the Major Industrialized Countries." Economics Letters 95 (1): 151-156.

Branson, Nicola, and Murray Leibbrandt. 2013. "Educational Attainment and Labour Market Outcomes in South Africa, 1994-2010." OECD Economics Department Working Paper No. 1022.

Bryan, Gharad, Shyamal Chowdhury, and Ahmed Mobarak. 2014. "Underinvestment in a Profitable Technology: The Case of Seasonal Migration in Bangladesh." Econometrica 82 (5): 1671-1748.

Budlender, Debbie. 2009. Industrial Relations and Collective Bargaining: Trends and Developments in South Africa. ILO Industrial and Employment Relations Department Working Paper No. 2.

Cacciatore, Matteo, Romain Duval, Giuseppe Fiori and Fabio Ghironi. 2016. "Market Reforms in the Time of Imbalance." Journal of Economic Dynamics and Control 72: 69-93.

Calmfors, Lars, and John Driffill. 1988. "Bargaining Structure, Corporatism and Macroeconomic Performance." Economic Policy 3(6): 13-61.

Card, David, Jochen Kluve, and Andrea Weber. 2018. "What Works? A Meta Analysis of Recent Active Labor Market Program Evaluations." Journal of the European Economic Association 16 (3): 894-931.

Crepon, Bruno, and Marianne Bertrand. 2020. "Teaching Labor Laws: Evidence from a Randomized Control Trial in South Africa." IZA Discussion Paper No. 13513.

Crepon, Bruno, and Gerard van den Bergh. 2016. "Active Labor Market Policies." Annual Review of Economics 8 (1), 526-546.

Diez-Catalan, Luis, and Ernesto Villanueva. 2015. "Contract Staggering and Unemployment During the Great Recession: Evidence from Spain." Working Paper 1431, Banco de España, Madrid. 
Duval, Romain and Davide Furceri. 2018. "The effects of Labor and Product Market Reforms: The Role of Macroeconomic Conditions and Policies." IMF Economic Review 66(1): 31-69.

Duval, Romain, Davide Furceri and Joao Jalles. 2019. "Job Protection Deregulation in Good and Bad Times." Oxford Economic Papers 72(2): 370-390.

Duval, Romain, Davide Furceri, Bingjie Hu, Joao Jalles and Huy Nguyen. 2018. "A Narrative Database of Major Labor and Product Market Reforms in Advanced Economies." IMF Working Paper No. 18/19.

Duval, Romain and Prakash Loungani. 2019. "Designing Labor Market Institutions in Emerging Market and Developing Economies: Evidence and Policy Options." IMF Staff Discussion Note No. 19/04, International Monetary Fund, Washington, DC.

Edmonds, Eric, Kristin Mammen and Douglas Miller. 2005. "Rearranging the Family? Income Support and Elderly Living Arrangements in a Low-Income Country." Journal of Human Resources 40 (1): 186-207.

Fabrizio, Stefania, Vivian Malta, and Marina Mendes Tavares. 2020. "COVID-19: A Backward Step for Gender Equality." VOXEU Blog, 20 June 2020.

Freeman, Richard. 2010. "Labor Regulations, Unions, and Social Protection in Developing Countries: Market Distortions or Efficient Institutions?" In Handbook of Development Economics, edited by Dani Rodrik and Mark Rosenzweig, (pp. 4657-702). Amsterdam: Elsevier.

Freeman, Richard, and James Medoff. 1984. What Do Unions Do? New York: Basic Books.

Godfrey, Shane. 2018. Multi-employer Collective Bargaining in South Africa. ILO Conditions of Employment and Work Series No. 97.

Godfrey, Shane, Johaa Maree and Jan Theron. 2006. Conditions and Employment of Small Business: Coverage, Compliance and Exemptions. University of Cape Town Development Policy Research Unit Working Paper No. 06/106.

Guner, Nezih, Remzi Kaygusuz and Gustavo Ventura. 2020. "Child-Related Transfers, Household Labor Supply and Welfare." Review of Economic Studies, March.

Hijzen, Alexander and Pedro Martins. 2016. "No Extension without Representation? Evidence from a Natural Experiment in Collective Bargaining." IMF Working Paper 16/143, International Monetary Fund, Washington, DC.

Hijzen, Alexander, Pedro Martins and Jante Parlevliet. 2017. "Collective Bargaining Through the Magnifying Glass: A Comparison between the Netherlands and Portugal." IMF Working Paper No. 17/275. 
International Labour Organization. 2002. "National Labour Law Profile: South Africa." Available at https://www.ilo.org/ifpdial/information-resources/national-labour-lawprofiles/WCMS 158919/lang--en/index.htm.

International Monetary Fund. 2020a. "Options to Support Incomes and Formal Employment During COVID-19." IMF Special Series on COVID-19. Available at https://www.imf.org/ /media/Files/Publications/covid19-special-notes/en-special-series-oncovid-19-options-to-support-incomes-and-formal-employment-during-covid-19.ashx?la =en.

International Monetary Fund. 2020b. "Options to Support the Incomes of Informal Workers During COVID-19." IMF Special Series on COVID-19. Available at https://www.imf.org/ /media/Files/Publications/covid19-special-notes/en-special-series-oncovid-options-to-support-the-incomes-of-informal-workers-during-covid-19.ashx?la=en.

International Monetary Fund. 2019. "Reigniting Growth in Emerging Market and Low-Income Economies: What Role for Structural Reforms?" IMF World Economic Outlook, Chapter 3, October.

International Monetary Fund. 2018. The Future of Work: Measurement and Policy Challenges. G-20 Background Note, July.

International Monetary Fund. 2016. "Time for a Supply-Side Boost? Macroeconomic Effects of Labor and Product Market Reforms in Advanced Economies" IMF World Economic Outlook, Chapter 3, April.

Jaumotte, Florence, and Carolina Osorio-Buitron. 2015. "Inequality and Labor Market Institutions." IMF Staff Discussion Note No. 15/14, International Monetary Fund, Washington, DC.

Jensen, Robert. 2012. "Do Labor Market Opportunities Affect Young Women's Work and Family Decisions? Experimental Evidence from India." Quarterly Journal of Economics 127 (2): 753-792.

Jimeno, Juan and Carlos Thomas. 2013. "Collective Bargaining, Firm Heterogeneity, and Unemployment." European Economic Review 59 (C): 63-79.

Levinsohn, James, Neil Rankin, Gareth Roberts and Volker Schoer. 2014. "Wage Subsidies and Youth Employment in South Africa: Evidence from a Randomized Control Trial." Stellenbosch Economic Paper No. 02/14.

Magruder, Jeremy. 2012. "High Unemployment Yet Few Small Firms: The Role of Centralized Bargaining in South Africa." American Economic Journal: Applied Economics 4 (3): 138-66.

McKenzie, David. 2017. "How Effective are Active Labor Market Policies in Developing Countries? A Critical Review of Recent Evidence." World Bank Research Observer 32 (2): 127-154.

Meth, Charles. 2011. "Employer of Last Resort? South Africa's Expanded Public Works Programme (EPWP)." Saldru Working Paper No. 58, Cape town: Southern Africa Labour and Research unit. 
Ngarachu, Maria, Axel Schimmelpfennig and Volker Schöer. 2014. "The Costly Road to Work? Wages and Transport Costs in South Africa." IMF Selected Issues Paper.

National Minimum Wage Panel. 2016. A National Minimum Wage for South Africa:

Recommendations on Policy and Implementation. National Minimum Wage Panel Report to the Deputy President:

http://www.treasury.gov.za/publications/other/NMW\%20Report\%20Draft\%20CoP\%20FINAL.PDF.

National Treasury. 2019. Economic Transformation, Inclusive Growth and Competitiveness: $A$ Contribution Towards a Growth Agenda for the South African Economy. Report prepared by the Economic Policy Division, National Treasury, Republic of South Africa.

Organisation for Economic Cooperation and Development. 2019. Negotiating our Way Up: Collective Bargaining in a Changing World of Work. OECD Publishing, Paris.

Organisation for Economic Cooperation and Development. 2018. Good Jobs for All in a Changing World of Work: The OECD Jobs Strategy. OECD Publishing, Paris.

Organisation for Economic Cooperation and Development. 2017. OECD Economic Surveys: South Africa. OECD Publishing, Paris.

Organisation for Economic Cooperation and Development. 2013. Improving Education Quality in South Africa, Chapter 1 in OECD Economic Surveys: South Africa, OECD Publishing, Paris.

Piek, Marlies, Dieter von Fintel, and Johann Kirsten. 2020. "Separating Employment Effects into Job Destruction and Job Creation: Evidence from a Large Minimum Wage Increase in the Agricultural Sector Using Administrative Tax Data." WIDER Working Paper No. 2020/51. United Nations University: World Institute for Development Economics Research.

Thakoor, Vimal. 2020. "Market Power, Growth and Inclusion: The South African Experience." IMF Working Paper No. 20/206. International Monetary Fund, Washington, DC.

Van Der Merwe, Jacomien, and Stephan Krygsman. 2020. "The Relationship between Transport Accessibility and Employment Duration." SA-TIED Working Paper No. 113. Southern Africa: Towards Inclusive Economic Development (SA-TIED).

Visser, Jelle. 2019. ICTWSS Data Base, Version 6.1. Amsterdam Institute for Advanced Labour Studies, October. 


\title{
VII. APPENDIX I. MODEL-BASED ANALYSIS OF WAGE BARGAINING REFORM IN SOUTH AFRICA
}

\begin{abstract}
43. This appendix provides detailed model-based analysis of the potential impact of wage bargaining reform-moving from sector-level wage bargaining to an individual firm level bargaining, or introducing flexible opening clauses —on structural unemployment. Ex ante, the impact of wage compression on unemployment in the presence of firm heterogeneity is ambiguous. On one hand, collective bargaining may not allow wages to adjust sufficiently to negative firm-specific shocks and could generate more job destruction. On the other hand, wage compression could incentivize job creation by not incorporating positive productivity shocks into wages and resulting higher profits for high productive jobs. To analyze these issues, and the impact of alternative wage bargaining systems on job flows and unemployment more broadly, we use the model developed by Jimeno and Thomas (2013), which we calibrate to the South African economy. This model is based on the search and matching framework developed by Mortensen and Pissarides (1994), where unemployment rate results from endogenous job creation and destruction. Wages are bargained through Nash bargaining with credible threats under two different regimes: firmlevel and sector-level bargaining. Under the firm-level bargaining regime, wages respond to firm-specific productivity. On the other hand, under the sector-level bargaining, wages respond to sector-wide average productivity. In both cases, job destruction and creations are determined by a productivity level and the firm-specific or sector-specific negotiated wages.
\end{abstract}

\section{A. Model description and calibration}

44. In each period, an unemployed worker receives a flow value of unemployment $\delta$ and in the next period an unemployed worker lands on a job with probability depending on labor market tightness (vacancy-to-unemployment ratio $\left.\theta=\frac{v}{u}\right)(\theta q(\theta)$ ), job not being destroyed exogenously immediately $(1-\rho)$, and drawing a high enough productivity level from a productivity distribution $\mathrm{F}(\mathrm{z})^{12}:(1-\mathrm{F}(\mathrm{R})$ ), where $\mathrm{R}$ is the (endogenous) productivity threshold below which a job is destroyed. If she doesn't land on a job, she continues to be unemployed. A worker with a productivity level $z$ receives a wage rate $w(z)$ in this period. In the next period, a worker loses a job either through some exogenous job destruction probability $\rho$ or draw a bad productivity level $(1-\rho) F(R)$. Otherwise, she continues to work with a new productivity level $z^{\prime}$. Each matched job with a productivity level $z$ receives a period return which is equal to a flow value of productivity minus the wage payment to the employee (z-w(z)). A vacancy is created with some cost $\kappa$ and will result in a filled job if the position is not exogenously destroyed and draws a high enough productivity level. If the negotiation fails, the firm incurs a disagreement $\operatorname{cost} \gamma$ and the worker receives a disagreement payoff, which is equal to the flow value of unemployment $\delta$.

\footnotetext{
${ }^{12}$ Productivity $\mathrm{z}$ is assumed to follow a log-normal distribution.
} 
45. Given the model setup above, the labor market dynamics can be described by the following law of motions.

$$
\begin{gathered}
n_{t}=(1-F(R))(1-\rho)\left(n_{t-1}+\theta q(\theta) u_{t-1}\right) \\
u_{t}=(\rho+(1-\rho) F(R)) n_{t-1}-\theta q(\theta)(1-\rho)(1-F(R)) u_{t-1}
\end{gathered}
$$

46. Thus, the steady state unemployment rate can be expressed as:

$$
u_{s s}=\frac{\rho+(1-\rho) F(R)}{\rho+(1-\rho) F(R)+\theta q(\theta)(1-\rho)(1-F(R))}
$$

47. Wages are negotiated differently under the firm-level and sector level bargaining regimes. Under the firm-level bargaining, the agreed wage is determined by the current productivity level $(z)$, flow value of unemployment $(\delta)$ and firm's cost of disagreement $(\gamma): w^{f}(z)=\frac{z}{2}+\frac{\delta+\gamma}{2}$. On the other hand, under the sector-level bargaining regime, wage is common across the firms with the sector and determined by the average productivity of the existing jobs $E(z \mid z \geq R)$, flow value of unemployment $(\delta)$ and firm's disagreement $\operatorname{cost}(\gamma): w^{S}=\frac{E(z \mid z \geq R)}{2}+\frac{\delta+\gamma}{2}$.

48. Table 2 below shows the values of calibrated parameters. We build a quarterly model. Discount rate $\beta \equiv \frac{1}{1+r} \quad$ is set at annual interest rate of 3.62 percent (average real interest rate in South Africa between 2001 and 2019), which implies a quarterly rate of, $r=0.008926$. Exogenous separation rate is set at $70 \%$ of total separation: of $\rho=.028$. Standard deviation of idiosyncratic ( $\log$ ) productivity, $\sigma$, is set to be 0.06 following Jimeno and Thomas $(2013)^{13}$. Mean idiosyncratic $\log$ productivity, $\mu$, is set to be $-\frac{\sigma^{2}}{2}$ so that a mean productivity level is normalized to be $1: E(z)=1$. Elasticity of matching function is set to be 0.5 following Petrongolo and Pissarides (2001): $\epsilon=0.5$. Scale parameter of the matching function $\left(\mathrm{m}(\mathrm{u}, \mathrm{v})=m_{0} u^{\epsilon} v^{1-\epsilon}\right)$ is set at $0.24\left(m_{0}=0.24\right)$ so that it is consistent with the job separation rates and job finding rates $\theta \mathrm{q}(\theta)$. Given the equilibrium values of reservation productivity $R$ and targeted labor market tightness $\frac{v}{u}$ is set at 0.25 as in Jimeno and Thomas (2013), sum of disagreement payoffs $\delta+\gamma$, (where $\delta$ is flow value of unemployment and $\gamma$ is firm's disagreement cost) becomes 0.975 , and vacancy posting cost, $\kappa$, becomes 0.134 . Finally, we target the steady state unemployment to be at 26 percent - an estimate of NAIRU in South Africa. To be consistent with the steady state unemployment, job finding rates under the sector-level bargaining are 0.11 and 0.04 , respectively. Both transition probabilities are in

\footnotetext{
${ }^{13}$ Using the South African Revenue Service's tax a dministrative data between 2009 and 2014, Hlatshwayo et al (2020) ca lculate firm-level productivity a s output per worker (labor productivity) where output is measured as firm's va lue added which is total sa les minus the cost of sales. Labor inputs are measured as the total number of workers in the firm weighted by the number of days worked. The mean and standard deviation of log productivity is 12.4 and 0.749 , resulting in relative standard deviation of $0.749 / 12.4=0.06$.
} 
line with he estimates of transition probabilities based on Quarterly Labor Force Survey between 2008Q1 and 2014Q3 in Anand, Kothari, and Kumar (2016).

\begin{tabular}{|l|c|l|l|}
\hline \multicolumn{4}{|c|}{ Table 2: Calibration of Model Parameters } \\
\hline Parameter & Notation & Value & Target/Source \\
\hline Discount rate & $\beta$ & .965 & Annual real interest rate $=3.62$ percent \\
\hline Exogenous Separation Rate & $\rho$ & .028 & $70 \%$ of all separations (JT, 2013) \\
\hline SD of idiosyncratic (log) productivity & $\sigma$ & 0.06 & Hlatshwayo et al (2020). \\
\hline Mean idiosyncratic (log) productivity & $\mu$ & $-\frac{\sigma^{2}}{2}$ & So that E(z)=1. \\
\hline Elasticity of matching function & $\epsilon$ & 0.5 & Petrongolo and Pissarides (2001) \\
\hline Scale parameter of matching function & $m_{0}$ & 0.24 & Job finding rate=11\% p.q \\
\hline Sum of disagreement payoffs & $\delta+\gamma$ & 0.975 & Total separation rate $=4 \%$ p.q \\
\hline Vacancy posting cost & $\kappa$ & 0.134 & Vacancy/Unemployment ratio=1/4 (JT, 2013) \\
\hline
\end{tabular}

\section{B. Results}

49. The Figure below plots the steady state unemployment rates, job finding rates, and job separation rates under the two bargaining regimes: sector-level and firm-level bargaining. The steady state level unemployment rate is

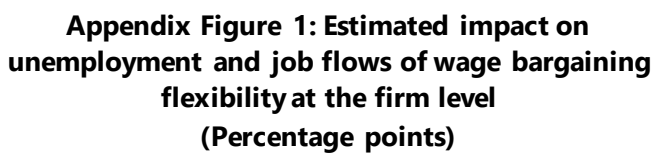

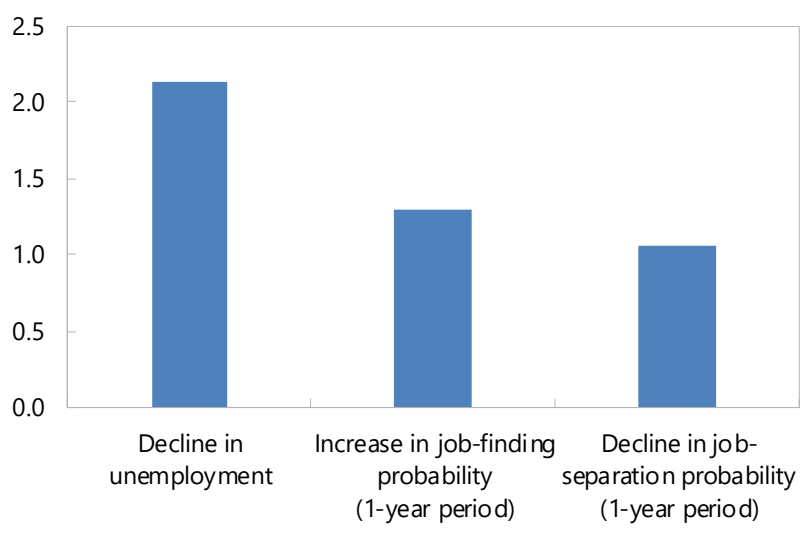

Source: World Bank Enterprise Surveys and IMF staff calculations. percent, while the job separation probability declines by 1.1 percentage points from 15.1 to 14. As a result, the steady state unemployment rate is estimated to decline by 8.6 percentage points to 17.5 percent. However, the results must be interpreted with caution. As Magruder (2012) points out, only about a quarter of employees work in two-digit industries in places with bargaining council coverage. Taking this into account, we estimate that flexible wage bargaining could reduce the unemployment rate by about 2 percentage points. 


\section{References}

Anand, Rahul, Siddharth Kothari, and Naresh Kumar. 2016. "South Africa: Labor Market Dynamics and Inequality" IMF Working Paper No. 16/137.

Hlatshwayo Ayanda, Friedrich Kreuser, Carol Newman, and John Rand. 2020. "Worker Mobility and Productivity Spillovers: An Emerging Market Perspective." SA-TIED Working Paper 88.

Jimeno, Juan and Carlos Thomas. 2013. "Collective Bargaining, Firm Heterogeneity, and Unemployment." European Economic Review 59 (C): 63-79.

Magruder, Jeremy. 2012. "High Unemployment Yet Few Small Firms: The Role of Centralized Bargaining in South Africa." American Economic Journal: Applied Economics 4 (3): 138-66.

Petrongolo, Barbara, and Christopher Pissarides. 2001. "Looking into the Black Box: A Survey of the Matching Function." Journal of Economic Literature 39 (2): 390-431.

Pissarides, Christopher. 2000. Equilibrium Unemployment Theory. The MIT Press, Second Edition. 